Article

\title{
Effects of Inorganic Salt Solutions on Vigour, Viability, Oxidative Metabolism and Germination Enzymes in Aged Cabbage and Lettuce Seeds
}

\author{
Ademola Emmanuel Adetunji ${ }^{1, *(\mathbb{D}, \text { Sershen }}{ }^{2,3}$, Boby Varghese ${ }^{1}$ and Norman W. Pammenter ${ }^{1}$ \\ 1 School of Life Sciences, University of KwaZulu-Natal, Durban 4001, South Africa; \\ varghese@ukzn.ac.za (B.V.); pammente@ukzn.ac.za (N.W.P.) \\ 2 Department for Biodiversity and Conservation Biology, University of the Western Cape, Private Bag X17, \\ Bellville 7535, South Africa; sershenn@gmail.com \\ 3 Institute of Natural Resources, P.O. Box 100396, Scottsville 3209, South Africa \\ * Correspondence: adetunjiademola@hotmail.com
}

Received: 29 June 2020; Accepted: 13 August 2020; Published: 9 September 2020

\begin{abstract}
This study assessed the potential of pre-hydration treatment with aqueous solutions (electrolysed [cathodic water; $\mathrm{CW}$ ] and non-electrolysed) prepared from four different inorganic ion combinations: $1 \mathrm{mM} \mathrm{CaCl}, 1 \mu \mathrm{m} \mathrm{CaCl}$ and $1 \mathrm{mM} \mathrm{MgCl} 2$ (CaMg, hereafter), $1 \mathrm{mM} \mathrm{MgCl}_{2}$ and $1 \mathrm{mM} \mathrm{NaCl}$ to invigorate controlled deteriorated (CDd) Brassica oleracea (cabbage) and Lactuca sativa (lettuce) seeds by assessing germination, vigour and biochemical markers (electrolyte leakage, lipid peroxidation products, protein carbonylation, and defence and germination associated enzymes) of oxidative stress. Additionally, the possible effects of $\mathrm{pH}$ of electrolysed $\mathrm{CaMg}$ and $\mathrm{NaCl}$ solutions were assessed. The inorganic salt solutions were applied to fresh seeds and seeds deteriorated to $75 \%$ viability (P75), $50 \%$ viability (P50) and $25 \%$ viability (P25); deionised water served as control. The pre-hydration treatment did not enhance normal seedling production in cabbage. However, Ca-containing and $\mathrm{CW}$ hydration treatments $\left(\mathrm{CaCl}_{2} \mathrm{CW}, \mathrm{CaMg}\right.$ and $\mathrm{CaMg} \mathrm{CW}$ [6.5], $\mathrm{MgCl}_{2} \mathrm{CW}, \mathrm{NaCl}$ $\mathrm{CW}$ and $\mathrm{NaCl} \mathrm{CW}$ [6.5]) promoted normal seedling production of $\mathrm{CDd}$ lettuce seeds, while seedling vigour was enhanced by $\mathrm{CaMg}, \mathrm{CaMg} \mathrm{CW}$ (6.5), $\mathrm{NaCl} \mathrm{CW}$ and $\mathrm{NaCl} C W$ (6.5) in CDd cabbage seeds, and $\mathrm{CaCl}_{2}, \mathrm{CaCl}_{2} \mathrm{CW}, \mathrm{CaMg}$, $\mathrm{CaMg} \mathrm{CW}$ (6.5), $\mathrm{MgCl}_{2} \mathrm{CW}, \mathrm{NaClCW}$ and $\mathrm{NaCl} \mathrm{CW}$ (6.5) in CDd lettuce seeds. The supplementation of $\mathrm{Ca}$, a component of the ionised solutes, and/or the reducing potential of CW contributed to increased normal seedling production in lettuce seeds irrespective of the $\mathrm{pH}$ of treatment solutions or degree of deterioration. Overall, the pre-hydration treatments enhanced endogenous antioxidants leading to reduced levels of electrolyte leakage, lipid peroxidation, protein carbonylation, and enhanced germination enzyme activities in lettuce seeds. The study concluded that pre-hydration with selected inorganic salt solutions can invigorate debilitated lettuce seeds.
\end{abstract}

Keywords: controlled deterioration; lipid peroxidation; electrolysed and non-electrolysed inorganic ions; germination; vigour

\section{Introduction}

At physiological maturity, characterised by low moisture content in orthodox seeds, germination and vigour are usually at the maximum level [1,2]. Mature seeds of orthodox species such as cabbage and lettuce $[3,4]$ can be stored for long periods when dried to moisture levels as low as $5 \%$ (fresh mass [FM] basis) or less and at low temperatures in dry conditions [3]. However, the seeds do not retain the initial quality with extended storage (years), gradually deteriorating, and inevitably proceeding towards death $[5,6]$. As seeds deteriorate, vigour is first lost, after which comes the loss of viability $[7,8]$. Poor yield, which is of crucial importance in crops, is a consequence of variable combinations of low 
germination, delayed emergence, weak seedling and/or abnormal seedlings and poor field stand, all of which are possible when debilitated seeds are sown [6].

This age-induced physiological deterioration of seeds in storage commonly referred to as ageing is brought about by high seed moisture content, temperature and relative humidity during storage $[6,9]$ but is also influenced by the genetic constitution of the seeds [10]. Susceptibility to ageing, and hence, the rate of deterioration in storage differs widely between species and among the varieties of related species due to factors such as storage condition and crop species diversity [11]. In several vegetable species, including cabbage [12,13] melon, pepper and lettuce [14], differences in the rates of seed deterioration during storage have been reported in relation to their storage conditions.

Ageing is intimately linked to the generation and accumulation of reactive oxygen species (ROS) that are highly reactive, toxic and capable of causing degradative reactions leading to severely damaging effects in seeds especially over an extended storage period $[15,16]$. Lipids, proteins, DNA and RNA, are believed to be the major ROS targets during oxidative stress [17], and the physiological lesions that result include loss of membrane integrity (through lipid peroxidation), reduced respiration, enzyme inactivation and degradation, and genetic degradation $[5,9,18]$. Lipid peroxidation, in particular, has been implicated in the loss of viability during storage of a number of crop seeds species $[19,20]$ and has been shown to lead to swelling of mitochondria, increased membrane viscosity and heightened bilayer permeability (measured as increased solute leakage) [5,21]. Products of lipid oxidation can also cause DNA damage and interrupt the normal functioning of a number of cellular systems [21].

Since seed deterioration is associated with loss of structural and metabolic integrity and biochemical abnormalities, evaluating the changes in the levels of oxidative stress biomarkers such as electrolyte leakage [21], lipid peroxidation [22], protein carbonylation [23], RNA and DNA integrity [9], antioxidant capacity [20] and activities of enzymes associated with germination [8] are useful ways of identifying the factors that enhance and alleviate ageing in seeds. Attempts to measure various physiological and biochemical indicators of oxidative stress have been employed in studies focused on assessing ageing-related metabolic changes in cabbage and lettuce. In cabbage, for instance, seed ageing has been related to changes in the levels of electrolyte leakage [24]. In lettuce, seed ageing has been attributed to changes in the levels of lipid hydroperoxides [25] and volatile products such as aldehydes and alcohols [26].

Given the global need to ensure food security for a rapidly growing world population in a changing climate through ex situ seed banking, limiting seed deterioration in storage and/or reinvigoration of seeds that have deteriorated to some extent in storage has been an increasingly important research focus. Controlled pre-sowing seed hydration to a point close to, but before radicle protrusion which allows for pre-germination metabolism without actual germination [6], is one of the techniques used for enhancing seed performance. Classical seed priming protocols originally developed decades ago, include but are not limited to biopriming, hydropriming and the use of non-permeating organic osmotica (osmoconditioning). These techniques have beneficial responses such as enhanced germination rate [27], germination capacity [28], and improved seedling vigour and stress tolerance [29]. Other beneficial effects like improved membrane integrity, antiperoxidative effects, mending of cellular lesions and metabolic elimination of harmful substances induced by oxidants have also been reported [30]. In this regard, seed pre-hydration treatments using synthetic and natural compounds have been reported to be quite effective in alleviating and repairing stress-induced cellular damage in several agriculturally important species, including cabbage [31,32] and lettuce [33,34]. Additionally, seed pre-germination treatments with inorganic salt solutions like $\mathrm{CaCl}_{2}$ [31], $\mathrm{MgSO}_{4}$ [34], $\mathrm{NaCl}$ [35] and $\mathrm{MgCl}_{2}$ [36] have been shown to have restorative effects in debilitated seeds.

The exact mechanisms through which these inorganic salts protect cells against oxidative stress and in turn have restorative effects in aged seeds of various orthodox species including cabbage and lettuce when hydrated with inorganic salt solutions are not well characterised. However, Ashraf and Rauf [37] suggested that seeds take up ions from saline solutions in which they are treated leading to increased accumulation of ions in varying proportions in the different parts of seeds during germination. Uptake 
of ions and existing ionic competition within cells is also affected by $\mathrm{pH}$ level [32,38]. The competition among protons, cations and anions is of key importance for plant mineral nutrition [38] as several findings have indicated that low $\mathrm{pH}$ levels are associated with cation uptake inhibition, while on the other hand, there may be slight or no influence on the uptake of anion [32]. This was part of the reasoning employed by Berjak et al. [39] in their development of an invigoration approach referred to as cathodic protection which involves treating zygotic embryos [40] and seeds [41] with the cathodic fraction of an electrolysed solution of calcium $(\mathrm{Ca})$ and magnesium $(\mathrm{Mg})$ chloride. The reduced cathodic fraction of an electrolysed dilute ionic solution, henceforth referred to as cathodic water (CW), has a high $\mathrm{pH}$ and has been reported to possess strong reducing antioxidative power [39,40,42]. It has been shown to enhance germination in stored seeds of Cucurbita maxima, Lycopersicon esculentum and Pisum sativum seeds [41]. However, unlike other restorative seed pre-treatments that involve inorganic ions, cathodic protection has not gained popularity in germplasm banks since the mechanisms via which these solutions improve germination and vigour in stored seeds are not well characterised. Importantly, reports of studies which evaluated the restorative effects of inorganic ions suggest that their effects also appear to be species-specific [41,43].

This motivated the present study which investigated the effects of the application of a range of inorganic salt solutions (electrolysed and non-electrolysed) on germination and seedling vigour in controlled deteriorated cabbage and lettuce seeds. While previous studies have only looked at $\mathrm{CW}$ generated from a combination of $\mathrm{CaCl}_{2}$ and $\mathrm{MgCl}_{2}[39,44]$ and $\mathrm{NaCl}[40,42]$, the present study looked at the cathodic fractions of $\mathrm{CaCl}_{2}$ and $\mathrm{MgCl}_{2}$ solutions also. Where the treatment alleviated the effects of ageing on vigour and viability, established physical and biochemical markers of oxidative stress and germinability was assayed to identify the mechanism(s) through which these inorganic salts protect cells against oxidative stress. The study also investigated whether $\mathrm{pH}$ levels of selected electrolysed inorganic salt solutions (viz. $\mathrm{CaMg}$ and $\mathrm{NaCl}$ ) influenced the effects of these inorganic salt solutions on selected physical and biochemical markers of oxidative stress and germinability.

\section{Results}

\subsection{Effect of the Application of Inorganic Salt Solutions on \% Seedling Production and Vigour of Cabbage and} Lettuce Seeds

Abnormal seedling (AS) production, one of the known symptoms of ageing-induced damage in germinating seeds, were observed in the present study. The occurrence of AS ranging between 1.5\% and $23.5 \%$ in cabbage and $0.5 \%$ and $19.0 \%$ in lettuce was observed only in the controlled deteriorated seeds across all inorganic salt hydration treatments (Table 1). The proportion of AS produced was reduced significantly in P25 cabbage seeds treated with $\mathrm{CaCl}_{2} \mathrm{CW}, \mathrm{CaMg}, \mathrm{CaMg} \mathrm{CW}, \mathrm{CaMg} \mathrm{CW}$ (6.5), $\mathrm{MgCl}_{2}, \mathrm{NaCl}, \mathrm{NaCl} \mathrm{CW}, \mathrm{NaCl} \mathrm{CW}$ (6.5), and in $\mathrm{P} 50$ cabbage seeds treated with $\mathrm{NaCl} C W$ (6.5) relative to DW-treated seeds. However, the proportion of AS produced was increased significantly in P25 lettuce seeds treated with $\mathrm{NaCl}$ relative to DW-treated seeds. 
Table 1. Effect of the application of inorganic salt solutions on abnormal seedling production (\%) in controlled deteriorated cabbage and lettuce seeds.

\begin{tabular}{|c|c|c|c|c|c|c|}
\hline \multirow{2}{*}{$\begin{array}{l}\text { Hydration } \\
\text { Treatments }\end{array}$} & AS (\%) for P75 & AS (\%) for P50 & AS (\%) for P25 & AS (\%) for P75 & AS (\%) for P50 & AS (\%) for P25 \\
\hline & Cabbage Seeds & Cabbage Seeds & Cabbage Seeds & Lettuce Seeds & Lettuce Seeds & Lettuce Seeds \\
\hline DW & $11.00 \pm 8.75^{\mathrm{NS}}$ & $18.50 \pm 10.89^{a}$ & $20.00 \pm 5.24^{\mathrm{a}}$ & $6.50 \pm 6.74^{\mathrm{NS}}$ & $11.50 \pm 9.18^{\mathrm{NS}}$ & $9.00 \pm 4.14^{b}$ \\
\hline $\mathrm{CaCl}_{2}$ & $5.50 \pm 5.21 \mathrm{NS}$ & $9.00 \pm 8.49 \mathrm{NS}$ & $12.50 \pm 8.67^{\mathrm{NS}}$ & $7.00 \pm 5.13^{\mathrm{NS}}$ & $9.00 \pm 7.33^{\mathrm{NS}}$ & $13.00 \pm 5.95^{\mathrm{NS}}$ \\
\hline $\mathrm{CaCl}_{2} \mathrm{CW}$ & $1.50 \pm 2.98 \mathrm{NS}$ & $7.50 \pm 6.95 \mathrm{NS}$ & $7.50 \pm 9.18^{b}$ & $3.00 \pm 4.66 \mathrm{NS}$ & $4.00 \pm 5.66 \mathrm{NS}$ & $7.00 \pm 7.63 \mathrm{NS}$ \\
\hline $\mathrm{CaMg}$ & $6.50 \pm 6.39 \mathrm{NS}$ & $12.50 \pm 3.34 \mathrm{NS}$ & $8.00 \pm 5.24^{b}$ & $3.00 \pm 04.66^{\mathrm{NS}}$ & $10.50 \pm 5.21 \mathrm{NS}$ & $8.50 \pm 6.21^{\mathrm{NS}}$ \\
\hline $\mathrm{CaMg}$ CW & $5.00 \pm 5.95^{\mathrm{NS}}$ & $17.50 \pm 7.39 \mathrm{NS}$ & $6.00 \pm 5.24^{b}$ & $3.50 \pm 4.50 \mathrm{NS}$ & $5.50 \pm 7.07^{\mathrm{NS}}$ & $11.00 \pm 4.66^{\mathrm{NS}}$ \\
\hline $\mathrm{CaMg} \mathrm{CW} \mathrm{(6.5)}$ & $7.00 \pm 5.55^{\mathrm{NS}}$ & $14.00 \pm 4.78^{\mathrm{NS}}$ & $10.00 \pm 4.78^{b}$ & $3.00 \pm 3.55^{\mathrm{NS}}$ & $4.00 \pm 3.02 \mathrm{NS}$ & $8.00 \pm 6.76^{\mathrm{NS}}$ \\
\hline $\mathrm{MgCl}_{2}$ & $6.50 \pm 6.39 \mathrm{NS}$ & $10.50 \pm 4.24^{\mathrm{NS}}$ & $8.00 \pm 4.78^{b}$ & $4.00 \pm 6.05^{\mathrm{NS}}$ & $2.50 \pm 5.63 \mathrm{NS}$ & $12.00 \pm 5.66^{\mathrm{NS}}$ \\
\hline $\mathrm{MgCl}_{2} \mathrm{CW}$ & $7.00 \pm 6.32 \mathrm{NS}$ & $13.50 \pm 5.21^{\mathrm{NS}}$ & $14.00 \pm 5.66^{\mathrm{NS}}$ & $1.50 \pm 2.98^{\mathrm{NS}}$ & $6.50 \pm 6.39 \mathrm{NS}$ & $11.00 \pm 5.13^{\mathrm{NS}}$ \\
\hline $\mathrm{NaCl}$ & $16.00 \pm 8.00^{\mathrm{NS}}$ & $23.50 \pm 6.57^{\mathrm{NS}}$ & $4.75 \pm 1.58^{\mathrm{b}}$ & $2.75 \pm 1.83^{\mathrm{NS}}$ & $18.00 \pm 3.70^{\mathrm{NS}}$ & $19.00 \pm 4.14^{\mathrm{a}}$ \\
\hline $\mathrm{NaCl} C W$ & $9.50 \pm 5.63 \mathrm{NS}$ & $7.50 \pm 4.14^{\mathrm{NS}}$ & $9.00 \pm 8.21^{b}$ & $0.50 \pm 1.41^{\mathrm{NS}}$ & $8.50 \pm 5.83^{\mathrm{NS}}$ & $10.50 \pm 6.02^{\mathrm{NS}}$ \\
\hline $\mathrm{NaCl} C W(6.5)$ & $8.00 \pm 4.78^{\mathrm{NS}}$ & $6.50 \pm 5.95^{b}$ & $9.00 \pm 5.95^{b}$ & $5.00 \pm 4.14^{\mathrm{NS}}$ & $6.00 \pm 5.66^{\mathrm{NS}}$ & $5.00 \pm 6.32 \mathrm{NS}$ \\
\hline
\end{tabular}

Values represent mean $\pm \mathrm{SD}(4 \times n=25) \%$ abnormal seedling production of cabbage and lettuce seeds exposed to deionised water (DW) and inorganic salt hydration treatments after $\mathrm{CD}$. Values labelled with different letters are significantly different $(p<0.05$, ANOVA) when compared across hydration treatments within each CD level. Cathodic water, CW; cathodic water adjusted to $\mathrm{pH}$ 6.5, CW (6.5); controlled deterioration, CD; abnormal seedling, AS; NS: not significantly different from value obtained with DW and therefore not considered in statistical comparisons. 
Percentage normal seedling production in cabbage seeds was not enhanced significantly by the application of inorganic salt solutions; rather, this was reduced in $\mathrm{CaCl}_{2}-$ and $\mathrm{CaCl}_{2} \mathrm{CW}$-treated P50 cabbage seeds relative to seeds soaked in deionised water (DW) (Table 2). In lettuce, however, normal seedling production was increased significantly in $\mathrm{P} 50$ seeds treated with $\mathrm{CaCl}_{2} \mathrm{CW}, \mathrm{CaMg}$ and $\mathrm{CaMg} \mathrm{CW}$ (6.5), and in $\mathrm{P} 25$ seeds treated with $\mathrm{CaCl}_{2} \mathrm{CW}, \mathrm{CaMg}, \mathrm{MgCl}_{2} \mathrm{CW}, \mathrm{NaCl} \mathrm{CW}$ and $\mathrm{NaCl} \mathrm{CW}$ (6.5) relative to seeds soaked in DW (Table 3).

Table 2. Effect of the application of inorganic salt solutions on normal seedling production (\%) in fresh and controlled deteriorated (CDd) cabbage seeds.

\begin{tabular}{ccccc}
\hline $\begin{array}{c}\text { Hydration } \\
\text { Treatments }\end{array}$ & $\begin{array}{c}\text { \% Normal } \\
\text { Seedlings for } \\
\text { Fresh Seeds }\end{array}$ & $\begin{array}{c}\text { \% Normal } \\
\text { Seedlings for CDd } \\
\text { (P75) Seeds }\end{array}$ & $\begin{array}{c}\text { \% Normal } \\
\text { Seedlings for CDd } \\
\text { (P50) Seeds }\end{array}$ & $\begin{array}{c}\text { \% Normal } \\
\text { Seedlings for CDd } \\
\text { (P25) Seeds }\end{array}$ \\
\hline $\mathrm{DW}$ & $89.00 \pm 9.26^{\mathrm{NS}}$ & $72.00 \pm 14.81^{\mathrm{NS}}$ & $43.00 \pm 10.64^{\mathrm{a}}$ & $20.00 \pm 3.02^{\mathrm{NS}}$ \\
$\mathrm{CaCl}_{2}$ & $94.00 \pm 6.76^{\mathrm{NS}}$ & $71.00 \pm 9.74^{\mathrm{NS}}$ & $26.00 \pm 7.09^{\mathrm{b}}$ & $17.00 \pm 7.33^{\mathrm{NS}}$ \\
$\mathrm{CaCl}_{2} \mathrm{CW}$ & $94.50 \pm 5.21^{\mathrm{NS}}$ & $78.50 \pm 10.01^{\mathrm{NS}}$ & $21.50 \pm 10.24^{\mathrm{b}}$ & $19.00 \pm 6.32^{\mathrm{NS}}$ \\
$\mathrm{CaMg}_{\mathrm{MaM} \mathrm{CW}}$ & $92.50 \pm 7.54^{\mathrm{NS}}$ & $63.50 \pm 12.91^{\mathrm{NS}}$ & $36.00 \pm 6.05^{\mathrm{NS}}$ & $23.50 \pm 10.13^{\mathrm{NS}}$ \\
$\mathrm{CaMg} \mathrm{NS}$ & $72.5 \pm 10.99^{\mathrm{NS}}$ & $49.50 \pm 9.30^{\mathrm{NS}}$ & $22.00 \pm 3.70^{\mathrm{NS}}$ \\
$\mathrm{Ca} \mathrm{CW}(6.5)_{\mathrm{MgCl}}$ & $96.50 \pm 5.83^{\mathrm{NS}}$ & $69.50 \pm 12.46^{\mathrm{NS}}$ & $48.00 \pm 7.41^{\mathrm{NS}}$ & $26.50 \pm 3.66^{\mathrm{NS}}$ \\
$\mathrm{MgCl}_{2} \mathrm{CW}$ & $95.00 \pm 7.01^{\mathrm{NS}}$ & $78.00 \pm 8.28^{\mathrm{NS}}$ & $35.00 \pm 9.50^{\mathrm{NS}}$ & $14.50 \pm 8.26^{\mathrm{NS}}$ \\
$\mathrm{NaCl}$ & $92.50 \pm 9.90^{\mathrm{NS}}$ & $75.50+11.60^{\mathrm{NS}}$ & $40.00 \pm 7.71^{\mathrm{NS}}$ & $21.50 \pm 10.68^{\mathrm{NS}}$ \\
$\mathrm{NaCl} \mathrm{CW}$ & $95.50 \pm 4.99^{\mathrm{NS}}$ & $59.00 \pm 4.14^{\mathrm{NS}}$ & $48.00 \pm 9.80^{\mathrm{NS}}$ & $24.50 \pm 7.84^{\mathrm{NS}}$ \\
$\mathrm{NaCl} \mathrm{CW}(6.5)$ & $94.00 \pm 8.00^{\mathrm{NS}}$ & $69.00 \pm 5.13^{\mathrm{NS}}$ & $34.00 \pm 10.25^{\mathrm{NS}}$ & $25.50 \pm 8.26^{\mathrm{NS}}$ \\
\hline
\end{tabular}

Values represent mean $\pm \mathrm{SD}(4 \times n=25) \%$ normal seedling production of the control (fresh seeds soaked in deionised water [DW] and all the inorganic salt solutions), and CDd (P75, P50 and P25) cabbage seeds exposed to DW and inorganic salt solutions. Values labelled with different letters are significantly different $(p<0.05$, ANOVA) when compared across hydration treatments at P50. Cathodic water, CW; cathodic water adjusted to pH 6.5, CW (6.5); NS: not significantly different from value obtained with DW and therefore not considered in statistical comparisons.

Table 3. Effect of the application of inorganic salt solutions on normal seedling production (\%) in fresh and controlled deteriorated (CDd) lettuce seeds.

\begin{tabular}{ccccc}
\hline $\begin{array}{c}\text { Hydration } \\
\text { Treatments }\end{array}$ & $\begin{array}{c}\text { \% Normal } \\
\text { Seedling for } \\
\text { Fresh Seeds }\end{array}$ & $\begin{array}{c}\text { \% Normal } \\
\text { Seedling for CDd } \\
\text { (P75) Seeds }\end{array}$ & $\begin{array}{c}\text { \% Normal } \\
\text { Seedling for CDd } \\
\text { (P50) Seeds }\end{array}$ & $\begin{array}{c}\text { \% Normal } \\
\text { Seedling for CDd } \\
\text { (P25) Seeds }\end{array}$ \\
\hline $\mathrm{DW}$ & $99.00 \pm 1.85^{\mathrm{NS}}$ & $73.50 \pm 9.78^{\mathrm{NS}}$ & $50.00 \pm 10.03^{\mathrm{b}}$ & $21.00 \pm 6.32^{\mathrm{b}}$ \\
$\mathrm{CaCl}_{2}$ & $100.00 \pm 0.00^{\mathrm{NS}}$ & $70.00 \pm 8.28^{\mathrm{NS}}$ & $58.00 \pm 11.51^{\mathrm{NS}}$ & $32.00 \pm 11.31^{\mathrm{NS}}$ \\
$\mathrm{CaCl}_{2} \mathrm{CW}$ & $100.00 \pm 0.00^{\mathrm{NS}}$ & $74.00 \pm 10.03^{\mathrm{NS}}$ & $67.00 \pm 12.42^{\mathrm{a}}$ & $39.00 \pm 11.06^{\mathrm{a}}$ \\
$\mathrm{CaMg}_{\mathrm{MaM} \mathrm{CW}}$ & $98.50 \pm 4.24^{\mathrm{NS}}$ & $76.50 \pm 10.57^{\mathrm{NS}}$ & $76.50 \pm 10.57^{\mathrm{a}}$ & $40.00 \pm 9.56^{\mathrm{a}}$ \\
$\mathrm{CaMg} \mathrm{Ng}$ & $100.00 \pm 0.00^{\mathrm{NS}}$ & $72.50 \pm 4.50^{\mathrm{NS}}$ & $63.00 \pm 5.95^{\mathrm{NS}}$ & $23.00 \pm 6.32^{\mathrm{NS}}$ \\
$\mathrm{MgCl}_{2}$ & $99.00 \pm 1.85^{\mathrm{NS}}$ & $76.50 \pm 5.83^{\mathrm{NS}}$ & $68.00 \pm 10.90^{\mathrm{a}}$ & $29.00 \pm 5.13^{\mathrm{NS}}$ \\
$\mathrm{MgCl}_{2} \mathrm{CW}$ & $99.00 \pm 1.85^{\mathrm{NS}}$ & $83.00 \pm 9.50^{\mathrm{NS}}$ & $68.00 \pm 10.90^{\mathrm{NS}}$ & $28.00 \pm 11.11^{\mathrm{NS}}$ \\
$\mathrm{NaCl}$ & $98.00 \pm 2.20^{\mathrm{NS}}$ & $71.00 \pm 11.06^{\mathrm{NS}}$ & $57.00 \pm 12.96^{\mathrm{NS}}$ & $39.00 \pm 10.20^{\mathrm{a}}$ \\
$\mathrm{NaClCW}$ & $100.00 \pm 0.00^{\mathrm{NS}}$ & $78.25 \pm 5.06^{\mathrm{NS}}$ & $50.00 \pm 9.07^{\mathrm{NS}}$ & $24.50 \pm 6.57^{\mathrm{NS}}$ \\
$\mathrm{NaCl} \mathrm{CW}(6.5)$ & $99.50 \pm 1.41^{\mathrm{NS}}$ & $74.00 \pm 6.76^{\mathrm{NS}}$ & $61.50 \pm 11.99^{\mathrm{NS}}$ & $40.00 \pm 14.18^{\mathrm{a}}$ \\
\hline
\end{tabular}

Values represent mean $\pm \mathrm{SD}(4 \times n=25) \%$ normal seedling production of the control (fresh seeds soaked in deionised water [DW] and all the inorganic salt solutions), and CDd (P75, P50 and P25) lettuce seeds exposed to DW and inorganic salt solutions. Values labelled with different letters are significantly different $(p<0.05$, ANOVA) when compared across hydration treatments within each controlled deterioration level. Cathodic water, CW; cathodic water adjusted to $\mathrm{pH}$ 6.5, CW (6.5); NS: not significantly different from value obtained with DW and therefore not considered in statistical comparisons.

In both fresh and controlled deteriorated (P75) cabbage seeds, seedling vigour index (SVI) was not influenced significantly by soaking in inorganic salt solutions (Table S1). Seedling vigour index in P50 cabbage seeds, however, was significantly increased relative to P50 DW-treated seeds when 
soaked in CaMg CW (6.5) and $\mathrm{NaCl} \mathrm{CW}$ (6.5). In P25 CDd cabbage seeds, SVI increased significantly relative to P25 DW-treated seeds when soaked in $\mathrm{CaMg}, \mathrm{NaCl} \mathrm{CW}$ and $\mathrm{NaCl} \mathrm{CW}$ (6.5) (Table 4).

Table 4. Effect of the application of inorganic salt solutions on seedling vigour index of controlled deteriorated (CDd) cabbage and lettuce seeds.

\begin{tabular}{|c|c|c|c|}
\hline \multirow{2}{*}{$\begin{array}{c}\text { Controlled } \\
\text { Deterioration Level }\end{array}$} & \multirow{2}{*}{ Treatments } & \multicolumn{2}{|c|}{ Seedling Vigour Index } \\
\hline & & Cabbage & Lettuce \\
\hline \multirow{11}{*}{ 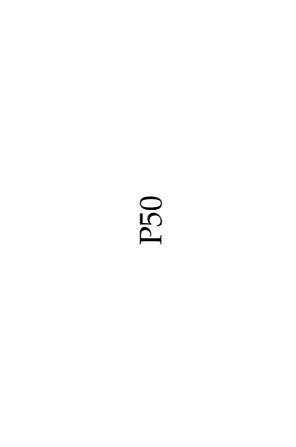 } & DW & $1621.40 \pm 911.97^{b}$ & $1056.90 \pm 323.25^{b}$ \\
\hline & $\mathrm{CaCl}_{2}$ & $1564.90 \pm 522.56^{\mathrm{NS}}$ & $2705.20 \pm 629.67^{a}$ \\
\hline & $\mathrm{CaCl}_{2} \mathrm{CW}$ & $1352.90 \pm 797.91 \mathrm{NS}$ & $2819.10 \pm 580.95^{a}$ \\
\hline & $\mathrm{CaMg}$ & $2855.00 \pm 688.79 \mathrm{NS}$ & $2823.50 \pm 585.35^{a}$ \\
\hline & $\mathrm{CaMg}$ CW & $2284.20 \pm 781.18^{\mathrm{NS}}$ & $1772.80 \pm 362.52 \mathrm{NS}$ \\
\hline & $\mathrm{CaMg}$ CW (6.5) & $3395.10 \pm 1073.31^{\mathrm{a}}$ & $3493.20 \pm 1077.06^{a}$ \\
\hline & $\mathrm{MgCl}_{2}$ & $3042.80 \pm 1570.89 \mathrm{NS}$ & $2525.20 \pm 607.15^{\mathrm{NS}}$ \\
\hline & $\mathrm{MgCl}_{2} \mathrm{CW}$ & $2938.70 \pm 776.86^{\mathrm{NS}}$ & $2755.80 \pm 1094.63^{a}$ \\
\hline & $\mathrm{NaCl}$ & $2644.10 \pm 1514.80^{\mathrm{NS}}$ & $2000.80 \pm 510.49 \mathrm{NS}$ \\
\hline & $\mathrm{NaClCW}$ & $2019.30 \pm 1042.40^{N S}$ & $2717.40 \pm 906.07^{\mathrm{a}}$ \\
\hline & $\mathrm{NaCl} C W(6.5)$ & $3520.30 \pm 910.90^{a}$ & $2981.20 \pm 795.30^{a}$ \\
\hline \multirow{11}{*}{$\stackrel{\leftarrow}{\aleph}$} & DW & $535.10 \pm 222.14^{b}$ & $403.30 \pm 199.74^{b}$ \\
\hline & $\mathrm{CaCl}_{2}$ & $903.00 \pm 597.52 \mathrm{NS}$ & $1090.93 \pm 404.74 \mathrm{NS}$ \\
\hline & $\mathrm{CaCl}_{2} \mathrm{CW}$ & $1198.40 \pm 534.58 \mathrm{NS}$ & $1341.80 \pm 362.03^{a}$ \\
\hline & $\mathrm{CaMg}$ & $1679.00 \pm 796.61^{\mathrm{a}}$ & $1144.80 \pm 405.07 \mathrm{NS}$ \\
\hline & CaMg CW & $531.50 \pm 294.91 \mathrm{NS}$ & $490.40 \pm 296.44^{\mathrm{NS}}$ \\
\hline & CaMg CW (6.5) & $1084.00 \pm 321.11^{\mathrm{NS}}$ & $794.40 \pm 395.29 \mathrm{NS}$ \\
\hline & $\mathrm{MgCl}_{2}$ & $785.50 \pm 627.33^{\mathrm{NS}}$ & $747.80 \pm 511.32 \mathrm{NS}$ \\
\hline & $\mathrm{MgCl}_{2} \mathrm{CW}$ & $1084.00 \pm 648.73^{\mathrm{NS}}$ & $1205.80 \pm 282.89 \mathrm{NS}$ \\
\hline & $\mathrm{NaCl}$ & $1438.70 \pm 426.89 \mathrm{NS}$ & $404.20 \pm 147.05^{\mathrm{NS}}$ \\
\hline & $\mathrm{NaClCW}$ & $1633.10 \pm 801.91^{\mathrm{a}}$ & $1493.80 \pm 668.57^{a}$ \\
\hline & $\mathrm{NaCl} C W(6.5)$ & $2205.18 \pm 1003.93^{a}$ & $1562.30 \pm 1038.11^{a}$ \\
\hline
\end{tabular}

Values represent mean \pm SD $(4 \times n=25)$ seedling vigour index (SVI) of CDd (P50 and P25) cabbage and lettuce seeds exposed to DW and inorganic salt solutions. Values labelled with different letters are significantly different $(p<0.05$, ANOVA) when compared across hydration treatments within each CD level. Cathodic water, CW; cathodic water adjusted to $\mathrm{pH}$ 6.5, CW (6.5); controlled deterioration, CD; NS: not significantly different from value obtained with DW and therefore not considered in statistical comparisons.

As in cabbage, in both fresh and P75 lettuce seeds SVI was not influenced significantly by inorganic salt solution application, compared with DW-treated seeds (Table S1). However, SVI in P50 lettuce seeds increased significantly relative to P50-DW-treated seeds when soaked in $\mathrm{CaCl}_{2}, \mathrm{CaCl}_{2} \mathrm{CW}$, $\mathrm{CaMg}, \mathrm{CaMg} \mathrm{CW}$ (6.5), $\mathrm{MgCl}_{2} \mathrm{CW}, \mathrm{NaCl} \mathrm{CW}$ and $\mathrm{NaCl} \mathrm{CW} \mathrm{(6.5)} \mathrm{while} \mathrm{SVI} \mathrm{in} \mathrm{P25} \mathrm{lettuce} \mathrm{seeds}$ increased significantly when treated with $\mathrm{CaCl}_{2} \mathrm{CW}, \mathrm{NaCl} \mathrm{CW}$ and $\mathrm{NaCl} \mathrm{CW}$ (6.5) compared with P25-DW-treated seeds (Table 4).

\subsection{Effect of the Application of Inorganic Salt Solutions on Biomarkers of Oxidative Stress in Lettuce Seeds}

The oxidative stress biomarkers were measured in control (fresh) and controlled deteriorated (CDd) lettuce seeds without soaking (unsoaked), and after soaking in DW; and in all those controlled deterioration $(\mathrm{CD}) \times$ inorganic salt treatment combinations that enhanced normal seedling production $(\%)$ significantly relative to DW-treated lettuce seeds at a specific level of CD. Since the treatments did not promote $\%$ normal seedling production in cabbage seeds, these assays were not performed for this species.

Leakage levels were significantly reduced in P50 lettuce seeds treated with CaMg CW (6.5) relative to DW-treated seeds (Figure 1A), but no hydration treatments (DW and inorganic salt) led to a significant reduction in leakage in P25 lettuce seeds relative to unsoaked seeds (Figure 2A). 


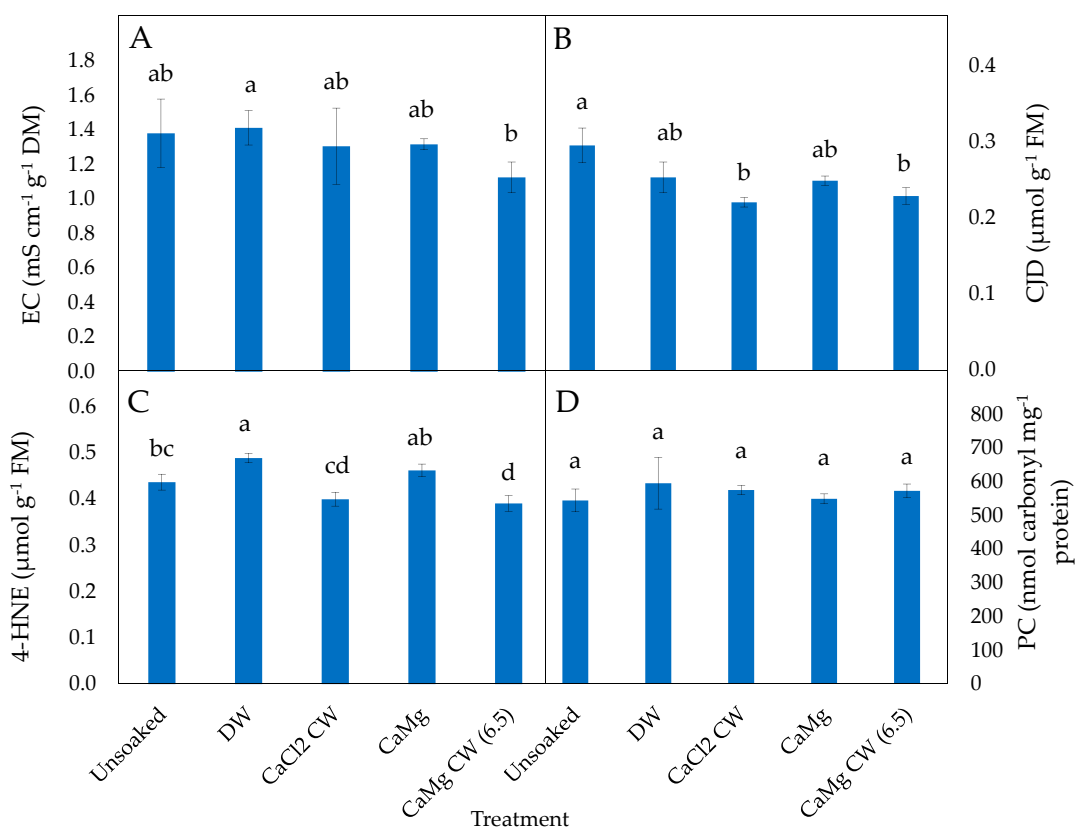

Figure 1. Effect of inorganic salt solution application on biomarkers of oxidative stress: (A) electrical conductivity (EC), (B) conjugated dienes (CJD), (C) 4-hydroxy-2-nonenal (4-HNE) and (D) protein carbonylation (PC) adduct, in controlled deteriorated P50 lettuce seeds subjected to no soaking or soaking in deionised water $(\mathrm{DW}), \mathrm{CaCl}_{2}$ generated cathodic water $\left(\mathrm{CaCl}_{2} \mathrm{CW}\right), \mathrm{CaMg}$, or $\mathrm{CaMg}$ generated cathodic water adjusted to $\mathrm{pH}$ 6.5 (CaMg CW [6.5]). Values represent mean $\pm \mathrm{SD}$ ( $n=5$ for $\mathrm{EC}$ and $n=3$ for all other parameters). Bars labelled with different letters indicate significant differences at $p<0.05$ (ANOVA).

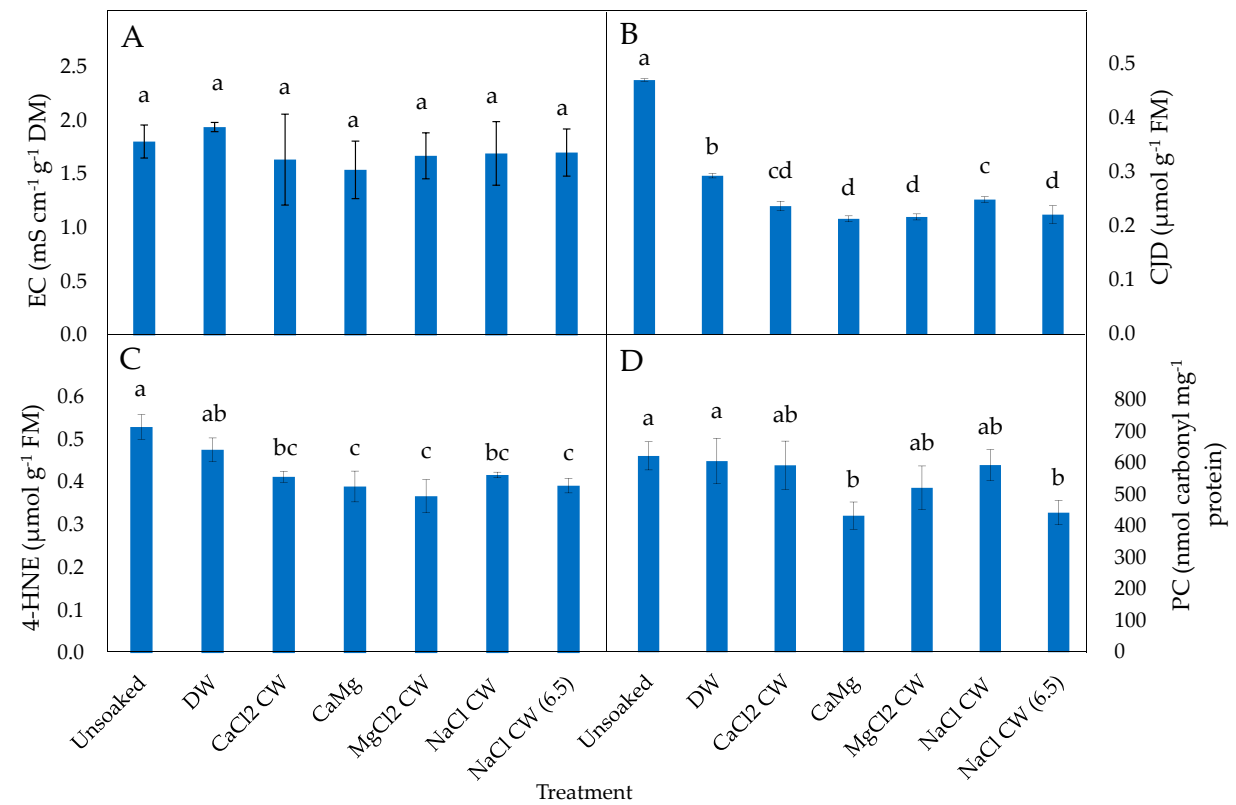

Figure 2. Effect of inorganic salt solution application on biomarkers of oxidative stress: (A) electrical conductivity (EC), (B) conjugated dienes (CJD), (C) 4-hydroxy-2-nonenal (4-HNE) and (D) protein carbonylation (PC) adduct, in P25 controlled deteriorated lettuce seeds subjected to no soaking or soaking in deionised water (DW), $\mathrm{CaCl}_{2}$ generated cathodic water $\left(\mathrm{CaCl}_{2} \mathrm{CW}\right), \mathrm{CaMg}, \mathrm{MgCl}_{2}$ generated cathodic water $\left(\mathrm{MgCl}_{2} \mathrm{CW}\right), \mathrm{NaCl}$ generated cathodic water $(\mathrm{NaCl} \mathrm{CW})$, or $\mathrm{NaCl}$ generated cathodic water adjusted to $\mathrm{pH} 6.5$ ( $\mathrm{NaClCW}[6.5])$. Values represent mean $\pm \mathrm{SD}(n=5$ for EC and $n=3$ for all other parameters). Bars labelled with different letters indicate significant differences at $p<0.05$ (ANOVA). 
Conjugated dienes (CJD) levels generally reduced after all hydration treatments but this was only significant in $\mathrm{P} 50$ seeds soaked in $\mathrm{CaCl}_{2} \mathrm{CW}$ and $\mathrm{CaMg} \mathrm{CW}$ (6.5), relative to unsoaked and DW-treated P50 seeds (Figure 1B). In P25 seeds, DW and all inorganic salt soaking treatments significantly reduced CJD levels relative to unsoaked P25 seeds; the inorganic salt treatments resulted in a greater reduction in CJD levels than DM (Figure 2B).

The levels of 4-HNE were significantly increased in DW-treated P50 seeds but significantly reduced when treated with CaMg CW (6.5), relative to unsoaked P50 seeds (Figure 1C). In P25 seeds, significantly reduced levels of 4-HNE relative to unsoaked P25 seeds were estimated for all inorganic salt treatments (Figure 2C).

The inorganic salt treatments did not lead to a significant reduction in protein carbonylation (PC) levels of P50 seeds (Figure 1D), while CaMg and $\mathrm{NaCl} \mathrm{CW} \mathrm{(6.5)} \mathrm{significantly} \mathrm{reduced} \mathrm{PC} \mathrm{levels} \mathrm{in} \mathrm{P25}$ seeds relative to unsoaked and DW-treated seeds (Figure 2D).

\subsection{Effect of the Application of Inorganic Salt Solutions on Enzymatic Antioxidant Activities of Lettuce Seeds}

In CDd P50 lettuce seeds, catalase (CAT) activity was not influenced significantly by the inorganic salt treatments relative to unsoaked seed but decreased significantly in seeds soaked in DW (Figure 3A). In P25 seeds, CAT activity was not influenced by $\mathrm{NaCl} \mathrm{CW}$ and $\mathrm{NaCl} \mathrm{CW} \mathrm{(6.5)} \mathrm{soaking} \mathrm{of} \mathrm{seeds} \mathrm{after}$ deterioration, relative to the unsoaked seeds but the enzyme activity decreased significantly in seeds soaked in $\mathrm{DW}, \mathrm{CaCl}_{2} \mathrm{CW}, \mathrm{CaMg}$ and $\mathrm{MgCl}_{2} \mathrm{CW}$ (Figure $4 \mathrm{~A}$ ).

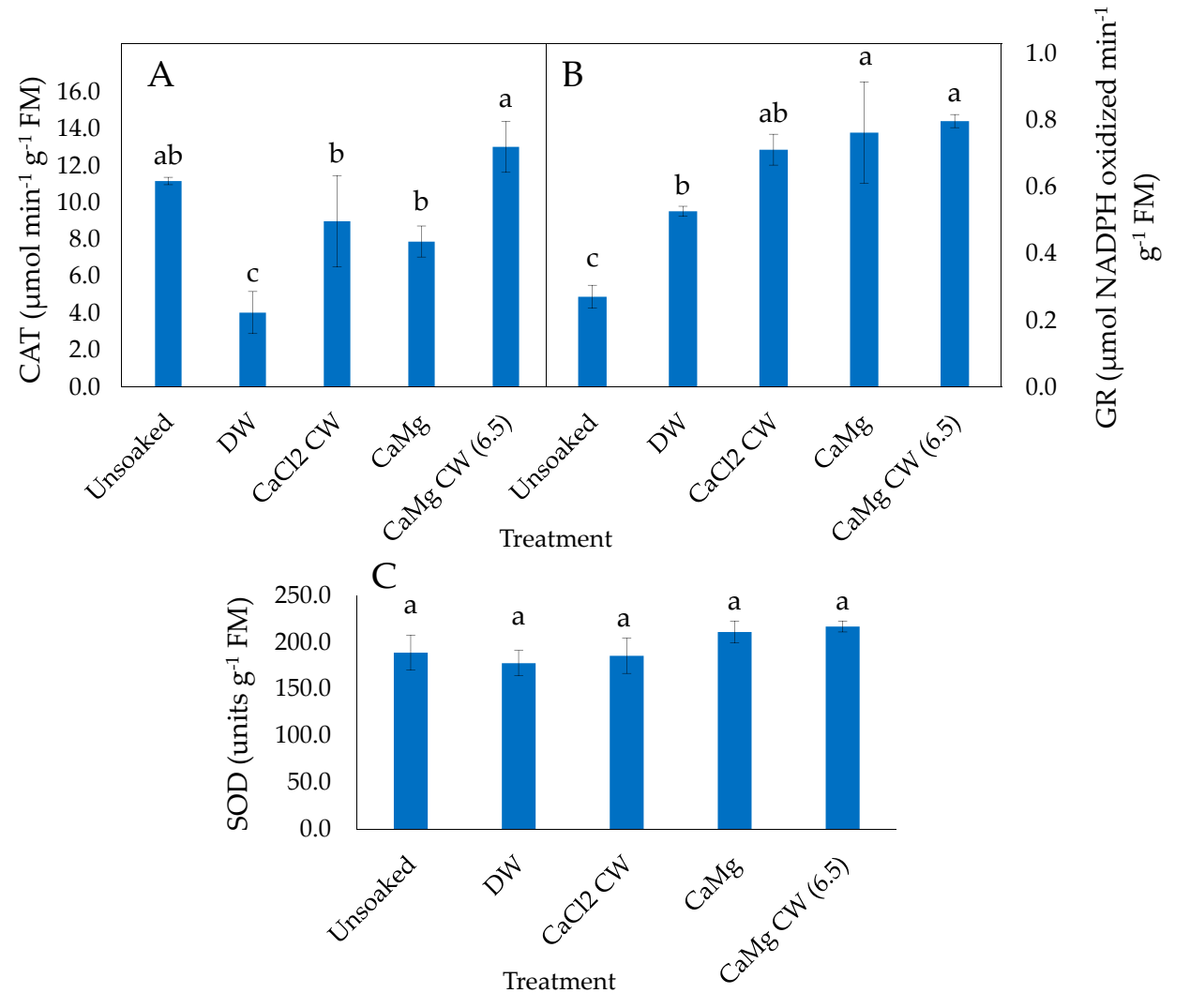

Figure 3. Effect of inorganic salt solution application on antioxidant enzymes activities: (A) catalase (CAT), (B) glutathione reductase (GR) and (C) superoxide dismutase (SOD), in P50 controlled deteriorated lettuce seeds subjected to no soaking or soaked in deionised water (DW), $\mathrm{CaCl}_{2}$ generated cathodic water $\left(\mathrm{CaCl}_{2} \mathrm{CW}\right), \mathrm{CaMg}$, or $\mathrm{CaMg}$ generated cathodic water adjusted to $\mathrm{pH} 6.5$ (CaMg CW [6.5]). Values represent mean $\pm \mathrm{SD}(n=3)$. Bars labelled with different letters indicate significant differences at $p<0.05$ (ANOVA). 


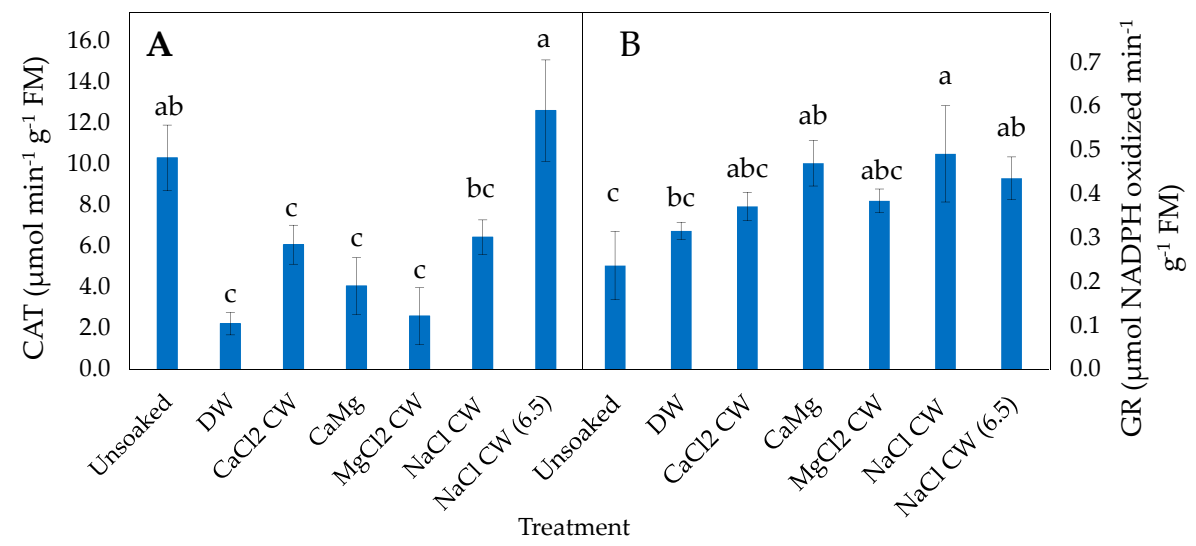

C

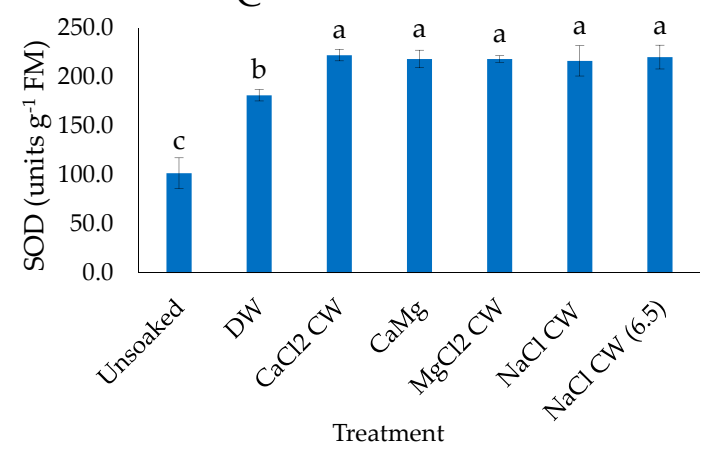

Figure 4. Effect of inorganic salt solution application on antioxidant enzymes activities: (A) catalase (CAT), (B) glutathione reductase (GR) and (C) superoxide dismutase (SOD), in P25 controlled deteriorated lettuce seeds subjected to no soaking or soaked in deionised water (DW), $\mathrm{CaCl}_{2}$ generated cathodic water $\left(\mathrm{CaCl}_{2} \mathrm{CW}\right), \mathrm{CaMg}, \mathrm{MgCl}_{2}$ generated cathodic water $\left(\mathrm{MgCl}_{2} \mathrm{CW}\right), \mathrm{NaCl}$ generated cathodic water $(\mathrm{NaCl} \mathrm{CW})$, or $\mathrm{NaCl}$ generated cathodic water adjusted to $\mathrm{pH} 6.5$ ( $\mathrm{NaCl} \mathrm{CW} \mathrm{[6.5]).}$ Values represent mean $\pm \mathrm{SD}(n=3)$. Bars labelled with different letters indicate significant differences at $p<0.05$ (ANOVA).

Glutathione reductase (GR) activity was increased significantly in P50 seeds in all the hydration treatments relative to the unsoaked seeds (Figure 3B). CaMg and CaMg CW (6.5) resulted in the highest GR activity among the hydration treatments. In CDd P25 seeds as well, GR activity was increased significantly by all hydration treatments ( $\mathrm{CaMg}, \mathrm{NaCl} \mathrm{CW}$ and $\mathrm{NaCl} \mathrm{CW} \mathrm{[6.5]),} \mathrm{relative} \mathrm{to} \mathrm{unsoaked}$ seeds (Figure 4B).

Superoxide dismutase (SOD) activity was not influenced significantly by any hydration treatment in P50 seeds relative to unsoaked seeds (Figure 3C). However, SOD activity in P25 seeds was increased significantly by all hydration treatments relative to unsoaked seeds; the inorganic salt treatments enhanced enzyme activity more than DW (Figure 4C).

\subsection{Effect of the Application of Inorganic Salt Solutions on Germination-Related Enzymes in Lettuce Seeds}

The inorganic salt solutions had a promotive effect on the activities of germination enzymes in the controlled deteriorated seeds. Though the hydration treatments did not significantly enhance $\alpha$-amylase activity in both P50 (Figure 5A) and P25 (Figure 6A) seeds relative to their unsoaked seeds, all hydration treatments significantly increased $\beta-1,3$-glucanase activity in P50 seeds relative to unsoaked seeds; $\mathrm{CaCl}_{2} \mathrm{CW}$ and $\mathrm{CaMg} \mathrm{CW}$ (6.5) soaked seeds exhibited the highest $\beta$-1,3-glucanase activity among the hydration treatments (Figure 5B).

In P25 seeds, $\beta$-1,3-glucanase activity was increased significantly by the hydration treatments relative to unsoaked seeds; $\mathrm{CaCl}_{2} \mathrm{CW}, \mathrm{NaCl}_{2} \mathrm{CW}$ and $\mathrm{NaCl}_{2} \mathrm{CW}$ (6.5) resulted in a greater rise in the enzyme activity than DW (Figure 6B). 


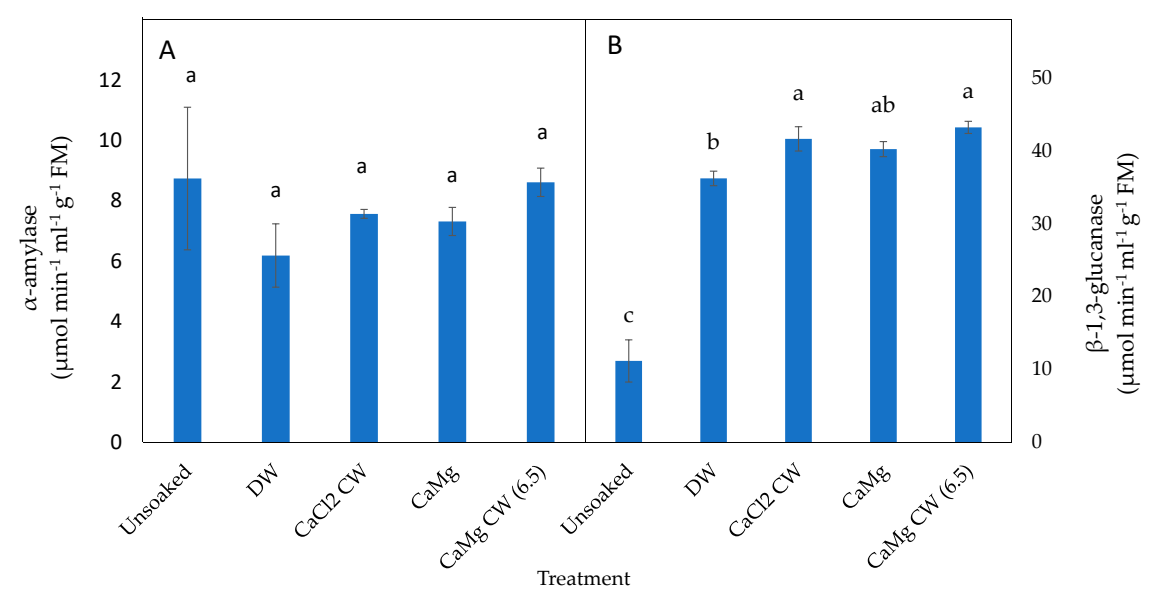

Figure 5. Effect of inorganic salt solution application on germination enzymes activities: (A) $\alpha$-amylase and (B) $\beta$-1,3-glucanase, in P50 controlled deteriorated lettuce seeds subjected to no soaking or soaked in deionised water (DW), $\mathrm{CaCl}_{2}$ generated cathodic water $\left(\mathrm{CaCl}_{2} \mathrm{CW}\right), \mathrm{CaMg}$, or $\mathrm{CaMg}$ generated cathodic water adjusted to $\mathrm{pH} 6.5$ (CaMg CW [6.5]). Values represent mean $\pm \mathrm{SD}(n=3)$. Bars labelled with different letters indicate significant differences at $p<0.05$ (ANOVA).

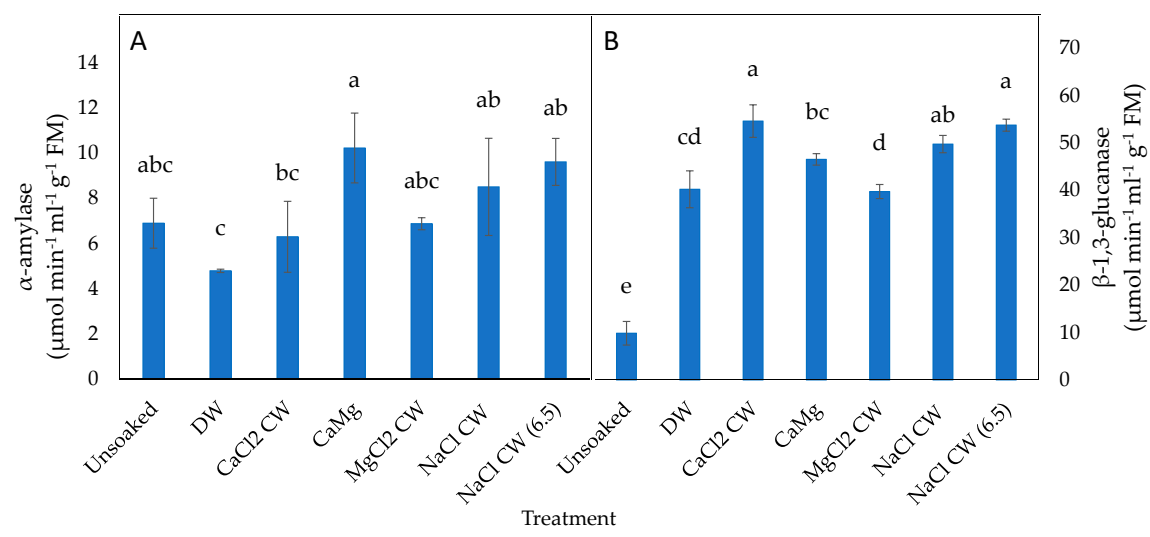

Figure 6. Effect of inorganic salt solution application on germination enzymes activities: (A) $\alpha$-amylase and (B) $\beta$-1,3-glucanase, in P25 controlled deteriorated lettuce seeds subjected to no soaking or soaked in deionised water (DW), $\mathrm{CaCl}_{2}$ generated cathodic water $\left(\mathrm{CaCl}_{2} \mathrm{CW}\right), \mathrm{CaMg}, \mathrm{MgCl}_{2}$ generated cathodic water $\left(\mathrm{MgCl}_{2} \mathrm{CW}\right), \mathrm{NaCl}$ generated cathodic water $(\mathrm{NaCl} \mathrm{CW})$, or $\mathrm{NaCl}$ generated cathodic water adjusted to $\mathrm{pH} 6.5$ ( $\mathrm{NaCl} \mathrm{CW}$ [6.5]). Values represent mean $\pm \mathrm{SD}(n=3)$. Bars labelled with different letters indicate significant differences at $p<0.05$ (ANOVA).

\section{Discussion}

Studies on the invigoration of debilitated orthodox seeds have employed various seed preconditioning treatments including organic [45] and inorganic [6] hydration agents where preconditioning treatments allow deteriorated seeds to partially regain their vigour, while consequently reducing the proportion of produced AS. In the present study, the significant reduction in the proportion of AS produced in cabbage seeds treated with inorganic salt (electrolysed and non-electrolysed) solutions relative to DW-treated CDd seeds (Table 1) was mainly accompanied by a significant increase in mortality (Table S2) and no significant increase in normal seedling production relative to DW-treated seeds (Table 2). Abnormal seedling production and delayed germination resulting from loss of vigour are expressions of advanced seed deterioration. Carrozzi et al. [34] reported that abnormal seedlings production was not changed compared with control in 1 year aged lettuce (Lactuca sativa) seeds hydrated with an inorganic salt $\left(\mathrm{MgSO}_{4}\right)$ solution. Tarquis and Bradford [46] also reported increased abnormal seedling production in L. sativa seeds pre-hydrated beyond $1 \mathrm{~h}$ after CD. In the present 
study, the treatment of controlled deteriorated lettuce seeds with the solution of inorganic ions $\left(\mathrm{CaCl}_{2}\right.$ $\mathrm{CW}, \mathrm{CaMg}$, $\mathrm{CaMg} \mathrm{CW}$ [6.5], $\mathrm{MgCl}_{2} \mathrm{CW}, \mathrm{NaCl} \mathrm{CW}$ and $\mathrm{NaCl} \mathrm{CW} \mathrm{[6.5])} \mathrm{improved} \mathrm{normal} \mathrm{seedling}$ production significantly (Table 3). Comparison with the results obtained for aged cabbage seeds with the same treatments suggests a species-specific effect of these inorganic ions on post $C D$ invigoration. These species-specific effects of specific inorganic salt solutions may be based on differences in the nature of the main oxidants and oxidant targets at the cellular level. According to Hawkins et al. [47], the nature of the predominant reactive oxidant has a substantial role to play in determining the level of impairment inflicted on their targets. Additionally, the potency of seed preconditioning agents on germination and seedling growth has been said to vary with species and the type of stress imposed [48].

However, it is worth noting that in aged lettuce seeds there were also differences in the effects of inorganic ion treatments between CD levels: CaMg CW (6.5) treatment improved normal seedling production at $\mathrm{P} 50$ and not in $\mathrm{P} 25 ; \mathrm{MgCl}_{2} \mathrm{CW}, \mathrm{NaCl} \mathrm{CW}$ and $\mathrm{NaCl} \mathrm{CW} \mathrm{(6.5)} \mathrm{were} \mathrm{significantly} \mathrm{effective}$ at $\mathrm{P} 25$ only (Table 3). On the other hand, $\mathrm{CaCl}_{2} \mathrm{CW}$ and $\mathrm{CaMg}$ hydration improved normal seedling production relative to DW soaking at both P50 and P25 in lettuce. In a previous study, Gondwe et al. [41] reported that preconditioning of seeds with electrolysed and non-electrolysed solutions of $\mathrm{CaMg}$ improved germination in seeds of Lycopersicon esculentum, Pisum sativum and Cucurbita maxima after storage for 4 months at $5{ }^{\circ} \mathrm{C}$. They attributed the beneficial effects to the strong reductive property of the electrolysed salt solution on ROS. In the present study, the enhancement of normal seedling production of lettuce seeds by the Ca containing solutions might be related to the supplementation of this divalent cation, a key second messenger that has been implicated in several oxidative stress alleviation responses [49], and/or the antioxidative potentials of CW [40,41] given that all solutions that showed a significant effect were $\mathrm{CW}$ solutions except where $\mathrm{Ca}$ was a component of the non-electrolysed inorganic salt solution. Whilst the ameliorative antioxidant effects of CW (generated using $2 \mathrm{mM} \mathrm{NaCl}$ solution) have been suggested to be related to the increased ionic product of the solvent water [42], the present study also underscores the relevance of the nature of the ionised solutes used to prepare the CW. Moreover, the mechanisms of action of the hydration treatments, perhaps, involves the fixing of ageing-induced oxidative stress alterations of ion channel activity [50] allowing for improved cellular functioning. The ion channel activity mentioned in the homeostatic modulation of the cellular ion channel is necessary to regulate cellular ion metabolic equilibrium that impacts on plant responses (adaptation to and dealing with) to various stress (abiotic and biotic) factors at the cellular level [50]. Extensive oxidative damage to receptors, transport proteins and ion channels can cause impaired cellular function [51,52]. Therefore, reactive oxidants can trigger $\mathrm{Ca}^{2+}$ - and $\mathrm{K}^{+}$-permeable channels in cell membranes leading to the rise in cytosolic $\mathrm{Ca}^{2+}$ [53] and leakage of $\mathrm{K}^{+}$[54] from the cell, respectively. As a second messenger known to be involved in several signalling responses $[49,50,55]$, the productivity and stress tolerance (abiotic and biotic) capacity of plants are influenced by their $\mathrm{Ca}^{2+}$ status [48] while oxidative stress-induced leakage of $\mathrm{K}^{+}$can stimulate programmed cell death [56].

Unlike the normal seedling production, which was only improved in controlled deteriorated lettuce seeds, the inorganic salt hydration treatment had a positive effect on SVI in both cabbage and lettuce seeds at P50 and P25 CD levels (Table 4). Post CD treatment with $\mathrm{NaCl}$ CW (6.5) showed a significant beneficial effect on SVI in both cabbage and lettuce seeds at both P50 and P25. Hydration with CaMg CW (6.5) also significantly improved the SVI in both species after CD to P50, whereas five other inorganic salt solutions $\left(\mathrm{CaCl}_{2}, \mathrm{CaCl}_{2} \mathrm{CW}, \mathrm{CaMg}, \mathrm{MgCl}_{2} \mathrm{CW}\right.$ and $\left.\mathrm{NaCl} \mathrm{CW}\right)$ were beneficial in improving SVI relative to the DW treated lettuce seeds only. At P25, $\mathrm{NaCl}$ CW was beneficial in both species while $\mathrm{CaMg}$ and $\mathrm{CaCl}_{2} \mathrm{CW}$ were beneficial in exhibiting higher SVI in cabbage and lettuce seeds, respectively. Treatment of aged seeds with $\mathrm{MgSO}_{4}$ solution has been reported to improve vigour in L. sativa [34] but at the time of this study, there were no previous reports of any of the inorganic ion solutions applied here shown to improve vigour in this species. Again, we attribute the beneficial effects recorded here to the ionic effect of the divalent cations. Gondwe et al. [41] reported that seed preconditioning with electrolysed and non-electrolysed solutions of CaMg improved SVI in seeds of Lycopersicon esculentum, Pisum sativum and Cucurbita maxima. Similarly, Iqbal and Ashraf [57] 
reported that seed preconditioning with $\mathrm{CaCl}_{2}$ solution promoted seedling vigour of Triticum aestivum under non-saline and even saline conditions. Other studies have shown the promotive effect of seed hydration on seedling vigour using low water potential osmotica solutions including $\mathrm{NaCl}(1 \mathrm{mM})$ in Capsicum annuum seeds subjected to salt stress [35], $\mathrm{CaCl}_{2}$ in Brassica napus seeds subjected to accelerated ageing [31] and $\mathrm{MgCl}_{2}$ [36] in Brassica oleracea seeds under standard germination conditions. However, almost all these studies have not gone to the extent of trying to understand the underlying biochemical changes responsible for improved normal seedling production and SVI due to inorganic salt hydration treatments.

On this note, the present study demonstrated that treatment with beneficial inorganic salt solutions significantly influenced some biochemical markers of oxidative stress in controlled deteriorated lettuce seeds. In effect, CaMg CW (6.5) significantly reduced EC levels in P50 lettuce seeds (Figure 1A) indicating that the inorganic salt hydration treatment had a restorative effect on lettuce seed membranes and reduced the heightened leakage of ions traditionally associated with ageing in seeds. Inorganic ions have been suggested to be involved in protecting cytoskeleton or cell membrane from injury [58] due to their promotive effect on the structure and stability of membrane lipid bilayer [58]. In addition, cation-enhanced interactions between lipids allow for closeness between lipid molecules thereby increasing membrane density [58]. In previous studies, Abdolahi et al. [31] reported that $\mathrm{KH}_{2} \mathrm{PO}_{4}$ solution lessened EC in three cultivars (RGS, 'Hyola 401' and 'Pacific') of Brassica napus seeds subjected to accelerated ageing for different durations (48 and $96 \mathrm{~h}$ ). However, they also showed that $\mathrm{CaCl}_{2}$ solution performed otherwise in the same study, while Sathish and Sundareswaran [59] found $\mathrm{CaCl}_{2}$, $\mathrm{KH}_{2} \mathrm{PO}_{4}$ and $\mathrm{KNO}_{3}$ inorganic salt hydration treatments to have no significant effect on the EC of three genotypes (UMI 61, UMI 285 and COH[M] 5) of aged Zea mays seeds. Overall, it appears that seed hydration treatments may have a promotive effect or be ineffective or even detrimental in some species [46].

The basis of exposing aged seeds to different soaking treatments is generally to enhance recovery from and/or reduce ageing-induced peroxidative changes. Lipid peroxidation products (CJD and 4-HNE) levels were reduced significantly by CaMg CW (6.5) in P50 lettuce seeds, and $\mathrm{CaCl}_{2} \mathrm{CW}$ reduced CJD levels in both P50 (Figure 1B) and P25 (Figure 2B) in this species. In P25 seeds of the same species, five inorganic salt treatment solutions (viz. $\mathrm{CaCl}_{2} \mathrm{CW}, \mathrm{CaMg}, \mathrm{MgCl}_{2} \mathrm{CW}, \mathrm{NaCl} \mathrm{CW}$ and $\mathrm{NaCl}$ CW [6.5]) significantly reduced CJD and 4-HNE while DW was only effective in CJD reduction (Figure 3B,C). Previous studies have reported that seed preconditioning led to the reduction of lipid peroxidation products in different plant organs and under various stress conditions. Chowdhury and Choudhuri [60], for instance, reported $\mathrm{CaCl}_{2}$ seed pre-hydration to reduce lipid peroxidation (malondialdehyde [MDA]) in water-stressed seeds of Corchorus capsularis and C. olitorius. Additionally, Khorshidi and Nojavan [61] reported reduced levels of MDA in the roots and shoots of cold stressed Zea mays seedlings produced from seeds pre-treated with $\mathrm{CaCl}_{2}$ solution. Those authors suggested that the inorganic salt hydration treatment enhanced antioxidative enzymes activity, thereby leading to reduced cold stress injury. Seed pre-soaking in water also reduced total peroxide and MDA levels in Momordica charantia seeds [62]. The present study shows that in addition to the strong reductive properties of $\mathrm{CW}$, the inorganic ions in the CW might be improving hydrolytic and antiperoxidative enzyme activities to offset lipid peroxidation effects [63]. Seed quality enhancement by seed hydration treatments has been ascribed to lessened ROS-mediated lipid peroxidation [64].

As products of stress-induced lipid peroxidation, certain reactive carbonyl species $(\alpha, \beta$-unsaturated ketones and aldehydes) have been implicated in the mediation of ROS signals leading to the modification of proteins [65]. The resultant oxidation of proteins leads to alterations in protein structural and functional properties [66]. Specific germination enzymes can also be carbonylated [23,67], resulting in loss of seed vigour. In the present study, the product of oxidative modification of proteins, measured as PC, was lowered significantly by CaMg and $\mathrm{NaCl} C W$ (6.5) in P25 lettuce seeds only (Figure 2D). This effect may be ascribed to the direct scavenging of ROS by CW and/or enhanced activities of endogenous antioxidative enzymes. Though not assessed in the present study, perhaps, 
the action of the inorganic salt hydration treatment might involve enhancement of injurious oxidant and carbonyl scavengers that constitute the non-enzymatic antioxidant defence system. As reported by Dell'Aquila [68], ageing stress led to the oxidative degradation of proteins in Triticum durum seeds. Oxidised (carbonylated) proteins are targeted for proteolysis [69], and if not degraded, can constitute a large molecular weight assemblage, which accrues with age [23]. The intracellular proteolysis resulting from the oxidation of specific amino acids may be involved in the stress-induced restructuring of plant metabolic process, as some reports have indicated that some species are more prone to proteolytic reactions than the others when exposed to stress [69].

High antioxidant activity is known to defend plants from oxidative damage accumulated due to oxidative stress thereby increasing their survival under stress conditions [70,71].This is achieved through the activities of free radicals and ROS detoxifying antioxidative enzymes such as CAT, GR, SOD, amongst others, which scavenge oxidants capable of attacking amino acids, proteins and lipids that are essential for cell functioning and integrity [70]. Reduced activities of antioxidant enzymes such as CAT, GR, SOD and POX in aged seeds cause lowered seed respiratory competency, and energy supply resulting in loss of viability [72]. The results of the present study show that the post CD hydration treatments did not have any significant effect on CAT activities but enhanced GR and SOD activity in lettuce seeds (Figure $3 \mathrm{~A}-\mathrm{C}$ and Figure 4A-C). More specifically, post CD soaking of seeds with DW and all tested inorganic salt solutions enhanced GR and SOD activity in P50 and P25 lettuce seeds, respectively, while $\mathrm{CaMg}, \mathrm{NaCl} \mathrm{CW}$ and $\mathrm{NaCl} \mathrm{CW} \mathrm{(6.5)} \mathrm{improved} \mathrm{GR} \mathrm{activity} \mathrm{in}$ P25 lettuce seeds only. The direct antioxidative properties of CW on ROS and the stimulation of endogenous antioxidant enzymes activities by the inorganic salt hydration treatments may, therefore, have contributed to the improvement in normal seedling production and seedling vigour observed in lettuce. Khorshidi and Nojavan [61] stated that cations, particularly $\mathrm{Ca}^{2+}$, can enhance the activities of most enzymatic antioxidants. At the same time, it is worth mentioning that soaking in water can also result in a rise in antioxidant enzymes, including GR and SOD activities (Momordica charantia [62]).

Seed germination enzymes are critical in the early growth stages of a germinating seed; most importantly, some of them are responsible for solubilising excess food stored as protein, lipid and starch to release energy for embryo development [43,73]. During germination, the process of mobilisation of stored food to the embryo is ubiquitous [43] but can be disturbed when already damaged seeds are exposed to stress conditions during germination, thereby exacerbating the damage. The degree of such disturbance depends on the levels and efficacy of germination associated enzymes involved in chemical reserve hydrolysis. It is envisaged that hydration of CDd seeds with inorganic salt solutions would have enhanced the germination enzymes activity, thereby contributing to organic substances mobilisation to various embryonic regions resulting in better germination and normal seedling establishment [43]. Hence, a rise in germination enzyme activity can result in improved vigour and viability. The present study revealed that the inorganic salt hydration treatments (electrolysed or non-electrolysed) did not influence $\alpha$-amylase activity (Figures 5A and 6A) significantly; however, all inorganic salt solutions examined as well as DW enhanced $\beta$-1,3-glucanase activity in both P50 and P25 lettuce seeds (Figures 5B and 6B). $\beta$-glucanases function in the hydrolysis of $\beta$-linked glucans and their activities can be regulated by abiotic and biotic stresses [74]. As various forms of $\beta$-glucans contribute to cell wall composition, the involvement of $\beta$-glucanases in processes that might alter cell walls structure and function is reasonable. There are suggestions that they influence cell wall matrix composition and viscoelastic properties which contribute to cell expansion [74,75]. The results of the present study, therefore, suggest that enhancement of $\beta-1,3$-ucanase activity by the hydration treatments may have contributed to the increased production of normal seedlings and vigour of debilitated lettuce seeds.

The results of the present study indicated that $\mathrm{CaMg} \mathrm{CW}(6.5)$ and $\mathrm{NaCl} \mathrm{CW} \mathrm{(6.5)} \mathrm{were} \mathrm{beneficial}$ in terms of promoting normal seedling production in CDd lettuce seeds, seedling vigor in CDd cabbage and lettuce seeds, ameliorating oxidative damage and enhancing antioxidative and germination-related enzyme activities in CDd lettuce seeds. There are reports of vegetable species (e.g., lettuce) growing 
better in solution-culture when $\mathrm{pH}$ is in the range of 7 [76]; however, the lack of information on the influence of $\mathrm{pH}$ on the effects of antioxidant-based soaking solutions on aged seeds suggests that this may represent a potential future area of research.

\section{Materials and Methods}

\subsection{Seed Material}

Brassica oleracea L. (cabbage, 'Glory of Enkhuizen') and Lactuca sativa L. (lettuce, 'Great Lakes') seeds supplied in airtight plastic bags were bought from McDonalds Seeds (Pietermaritzburg, South Africa), stored at $4{ }^{\circ} \mathrm{C}$ and used in less than 3 months of storage after purchase.

\subsection{Seed Vigour Assessment}

An initial germination and vigour test (three trials of $n=25$ ) was conducted for every seed lot before being exposed to the $\mathrm{CD}$ and application of inorganic salt solutions as described below. Only high vigour seed lots (germination $>85 \%$ in cabbage and germination $>95 \%$ in lettuce 2 days after sowing [DAS]) were used for assays that follow.

\subsection{Controlled Deterioration}

Seed moisture content (MC, \% fresh mass [FM]) was determined using the low-temperature oven method [77], while CD was performed according to Tekrony [78], with slight modifications (Figure 7) as shown below.

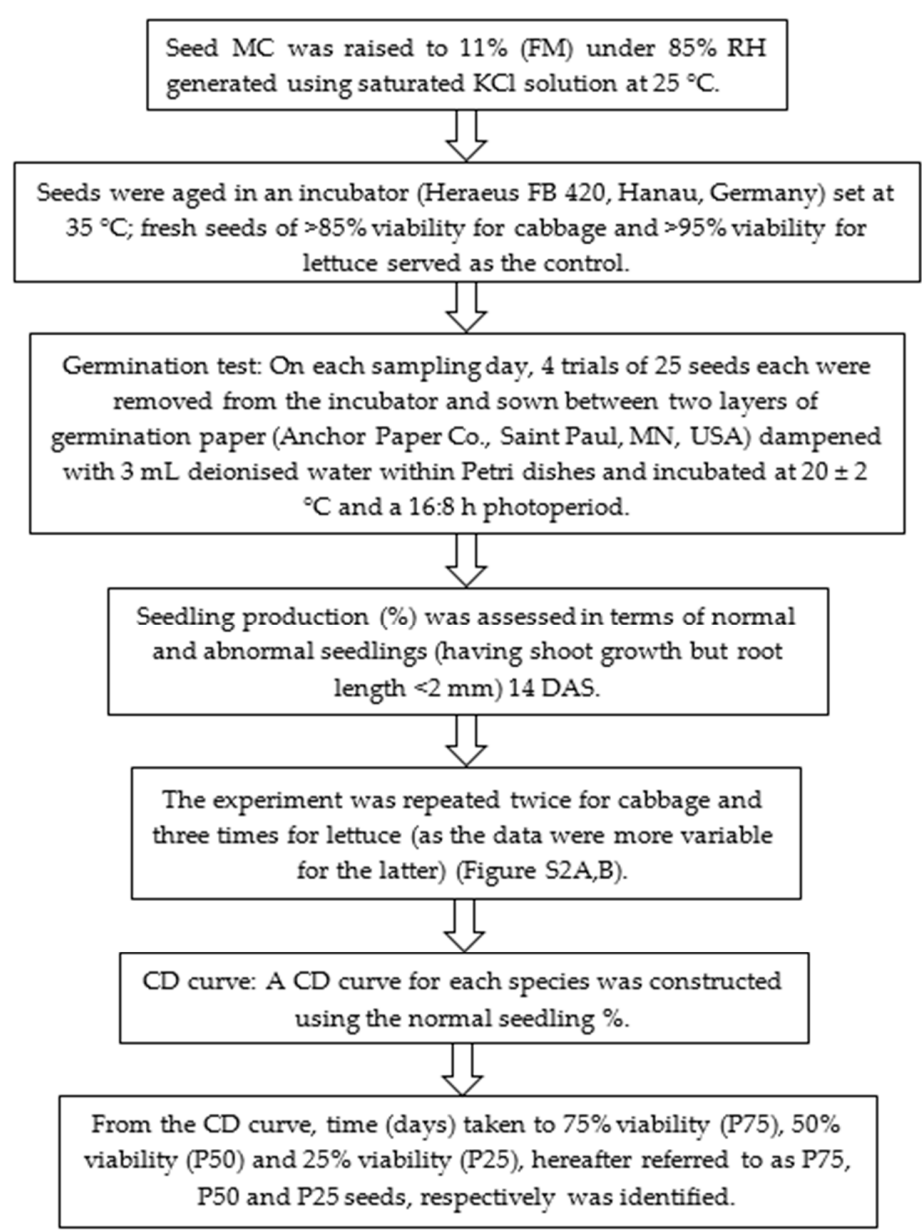

Figure 7. Steps followed to generate controlled deterioration (CD) curves used in this study (modified after Tekrony [78]). Days after sowing, DAS; controlled deterioration, CD. 


\subsection{Preparation of Inorganic Salt Solutions}

In this study, seeds were treated with non-electrolysed and the electrolysed CW (after Berjak et al. [39] of four inorganic salt solutions, viz. $\mathrm{CaCl}_{2}, \mathrm{CaMg}$ [79], $\mathrm{MgCl}_{2}$ and $\mathrm{NaCl}$ (Table 5).

Table 5. Seed pre-hydration treatment solutions used in this study to hydrate fresh and deteriorated seeds of cabbage and lettuce.

\begin{tabular}{|c|c|c|c|}
\hline $\mathrm{S} / n$ & Pre-Hydration Treatment Solution & Concentration of Constituent(s) & $\mathrm{pH}$ \\
\hline 1 & Control & Deionised water & 5.6 \\
\hline 2 & $\mathrm{CaCl}_{2}$ (non-electrolysed) & $1 \mathrm{mM} \mathrm{CaCl}_{2}$ & 6.0 \\
\hline 3 & $\mathrm{CaCl}_{2}$ generated $\mathrm{CW}$ & $1 \mathrm{mM} \mathrm{CaCl}_{2}$ & 10.8 \\
\hline 4 & CaMg (non-electrolysed) & $1 \mu \mathrm{m} \mathrm{CaCl} 2 ; 1 \mathrm{mM} \mathrm{MgCl}_{2}$ & 5.9 \\
\hline 5 & $\mathrm{CaMg}$ generated CW & $1 \mu \mathrm{m} \mathrm{CaCl}{ }_{2} ; 1 \mathrm{mM} \mathrm{MgCl}_{2}$ & 11.2 \\
\hline 6 & $\mathrm{CaMg}$ generated $\mathrm{CW}$ adjusted to $\mathrm{pH} 6.5$ & $1 \mu \mathrm{m} \mathrm{CaCl} 2 ; 1 \mathrm{mM} \mathrm{MgCl}_{2}$ & 6.5 \\
\hline 7 & $\mathrm{MgCl}_{2}$ solution (non-electrolysed) & $1 \mathrm{mM} \mathrm{MgCl}_{2}$ & 5.9 \\
\hline 8 & $\mathrm{MgCl}_{2}$ generated $\mathrm{CW}$ & $1 \mathrm{mM} \mathrm{MgCl} 2$ & 10.6 \\
\hline 9 & $\mathrm{NaCl}$ solution (non-electrolysed) & $1 \mathrm{mM} \mathrm{NaCl}$ & 5.6 \\
\hline 10 & $\mathrm{NaCl}$ generated $\mathrm{CW}$ & $1 \mathrm{mM} \mathrm{NaCl}$ & 11.2 \\
\hline 11 & $\mathrm{NaCl}$ generated $\mathrm{CW}$ adjusted to $\mathrm{pH} 6.5$ & $1 \mathrm{mM} \mathrm{NaCl}$ & 6.5 \\
\hline
\end{tabular}

To generate $\mathrm{CW}$ from any of the inorganic salt solutions used here, the solution was electrolysed using a BioRad ${ }^{\mathrm{TM}}$ Powerpac (BioRad, Hercules, CA, USA) equipped with two platinum electrodes. Each electrode was immersed in a $250 \mathrm{~mL}$ glass beaker containing $200 \mathrm{~mL}$ of the inorganic salt solution. Charge balance was maintained within the internal circuit by an agar-based salt bridge $(30 \% \mathrm{KCl}$ and $3 \%$ agar bacteriological), after which the solution was electrolysed at $60 \mathrm{~V}$ potential difference and $400 \mathrm{~mA}$ for $60 \mathrm{~min}$. As mentioned above, only the cathodic fraction was used for seed treatments, within $24 \mathrm{~h}$ of preparation [80].

To evaluate the possible influence, if any, of $\mathrm{pH}$ given that electrolysis of ionic solutions can raise the $\mathrm{pH}$ of the cathodic fraction significantly (in the range of 9 and above [42]) after 60 min (the duration used in the present study), the $\mathrm{pH}$ of $\mathrm{CaMg}$ and $\mathrm{NaCl}$ solutions (randomly selected) was adjusted to 6.5 with $1 \mathrm{M} \mathrm{HCl}$ solution.

\subsection{Application of Inorganic Salt Hydration Treatment}

Firstly, a hydration curve was generated for each species by hydrating (using $3 \mathrm{~mL}$ DW) three replicates of 25 seeds (cabbage, $0.08 \mathrm{~g}$; lettuce, $0.02 \mathrm{~g}$ ) placed between two discs of germination paper (Anchor Paper Co., Saint Paul, MN, USA), one below and the other above, in Petri dishes $(90 \times 15 \mathrm{~mm})$ at laboratory temperature of $23 \pm 2{ }^{\circ} \mathrm{C}$. The Petri dishes were covered and sealed with parafilm to prevent drying out. They were left for imbibition on a benchtop shaker (Labcon SPO 15-MP orbital, Maraisburg, South Africa) set at $100 \mathrm{rpm}$. At 2-h intervals, the seeds were blotted with a paper towel, weighed and returned to the moistened Petri dish. The process was repeated until the first signs of radicle protrusion ( $2 \mathrm{~mm}$ long). The data was then used to identify the hydration time required to reach the early germination phase (phase 2) but before radicle protrusion [33]. Once generated, these curves indicated that $8 \mathrm{~h}$ for cabbage and $6 \mathrm{~h}$ for lettuce were suitable hydration times for the seed treatments (Figure S1).

For treatment applications, four trials of $n=25$ of fresh and controlled deteriorated (P75, P50 and P25) seeds of both species were hydrated in $3 \mathrm{~mL}$ of DW and seed treatment solutions (Table 5), as described for the hydration curve, for a period of 8 and $6 \mathrm{~h}$ for cabbage and lettuce, respectively. The seed exterior was then dried with blotting paper and seeds were germinated as outlined under CD experiments (Figure 7). The seeds used for this experiment were hydrated without drying back as there have been reports of delayed germination and/or emergence when primed seeds are dried back relative to primed but not dried back seeds owing to the extra time needed for rehydration [81]. Seedling production (normal and abnormal) and seedling vigour index were assessed 14 DAS. 


\subsubsection{Assessment of Oxidative Stress and Germinability Biomarkers}

Where inorganic salt hydration treatment of seeds enhanced normal seedling production relative to the control significantly ( $p<0.05$, ANOVA), estimation of electrical conductivity (EC) and other biomarkers of oxidative stress and germinability was performed. For comparison, unsoaked and DW-soaked seeds were used as controls. All soaked seeds were blotted before use in any assay.

\section{Electrolyte Conductivity}

Electrolyte conductivity was evaluated with a multi-cell (CM100-2) conductivity meter (Reid \& Associates, Durban, South Africa) following the method of Sershen et al. [82] with slight modifications. Individual seeds $(n=5)$ were soaked in $2 \mathrm{~mL}$ of inorganic salt solution or DW for $8 \mathrm{~h}$. The EC was then determined using $1.5 \mathrm{~mL}$ of the solution. Thereafter, the dry mass (DM) of each seed was determined. Leakage was represented as average conductivity after $8 \mathrm{~h}$ less the conductivity of DW and the respective inorganic salt solutions used as blanks, in $\mathrm{mS} \mathrm{cm}^{-1} \mathrm{~g}^{-1} \mathrm{DM}$.

\section{Conjugated Dienes}

This was estimated following the method described by Parkhey et al. [22]. Seeds (three replicates of $0.25 \mathrm{~g}$ each) were homogenised in $4 \mathrm{~mL}$ of methanol containing $0.02 \%(w / v)$ EDTA, $1 \%(w / v) \mathrm{NaCl}$ and $2 \mathrm{~mL}$ chloroform. The homogenate was centrifuged (Model J-E, Beckman Coulter Avanti ${ }^{\circledR}$, La Brea, CA, USA) for $20 \mathrm{~min}$ at $11,000 \mathrm{~g}$ and $4{ }^{\circ} \mathrm{C}$. From the chloroform phase, a $100 \mu \mathrm{L}$ aliquot was taken and dried under a nitrogen gas stream. This was solubilised in $2 \mathrm{~mL}$ ethanol and the absorbance measured at $234 \mathrm{~nm}$. Conjugated diene levels were computed with an extinction coefficient of $25 \mathrm{mM}^{-1} \mathrm{~cm}^{-1}$ and expressed in $\mu \mathrm{mol} \mathrm{g}^{-1}$ fresh mass (FM).

\section{4-Hydroxy-2-Nonenal (4-HNE)}

This was estimated following the method described by Parkhey et al. [22]. Three replicates of $0.25 \mathrm{~g}$ seeds each were ground with $2 \mathrm{~mL}$ of $0.2 \mathrm{M}$ borate buffer $(\mathrm{pH} 7.4)$ and $750 \mu \mathrm{L}$ of $10 \%(w / v)$ TCA. The homogenate was centrifuged (Model J-E, Beckman Coulter Avanti ${ }^{\circledR}$, La Brea, CA, USA) for $20 \mathrm{~min}$ at $11,000 \mathrm{~g}$ and $4{ }^{\circ} \mathrm{C}$. An aliquot of $1 \mathrm{~mL}$ was then added to $1 \%(w / v) \mathrm{DNPH}(1 \mathrm{~mL})$ dissolved in $0.5 \mathrm{M}$ hydrochloric acid and incubated for $2 \mathrm{~h}$ at room temperature. This was precipitated with hexane $(2 \mathrm{~mL})$ and the precipitate was dried under a nitrogen gas stream. This was solubilised in methanol $(2 \mathrm{~mL})$, and absorbance was measured at $350 \mathrm{~nm}$. The level of 4-HNE was computed with an extinction coefficient of $13,750 \mathrm{M}^{-1} \mathrm{~cm}^{-1}$ and expressed in mmol g${ }^{-1} \mathrm{FM}$.

\section{Protein Carbonylation Evaluation}

Protein extraction was carried out according to Juszczuk et al. [66]. Total protein content was estimated following Bradford [83] and brought to a concentration of $10 \mathrm{mg} \mathrm{mL}^{-1}$ using DW. Protein carbonylation was estimated using the spectrophotometric method described by Augustyniak et al. [84] with slight modifications. A solution $(100 \mu \mathrm{L})$ of $10 \mathrm{mM} \mathrm{DNPH}$ in $\mathrm{HCl}(2.5 \mathrm{M})$ was mixed with $100 \mu \mathrm{L}$ of protein. The solution was vortexed and kept in the dark at room temperature for $10 \mathrm{~min}$. Then, $30 \mu \mathrm{L}$ of TCA solution was added, and the solution was kept on ice for 5 min and centrifuged (Model J-E, Beckman Coulter Avanti ${ }^{\circledR}$, La Brea, CA, USA) for $10 \mathrm{~min}$ at 13,000 g. The supernatant was discarded, and the pellet solubilised in $500 \mu \mathrm{L}$ of chilled acetone and sonicated for $30 \mathrm{~s}$. This mixture was kept for $5 \mathrm{~min}$ at $-20^{\circ} \mathrm{C}$ and centrifuged (Model J-E, Beckman Coulter Avanti ${ }^{\circledR}$, La Brea, CA, USA) for $2 \mathrm{~min}$ at $13,000 \mathrm{~g}$ and $4^{\circ} \mathrm{C}$. The pellet was washed with acetone and sonicated briefly in $6 \mathrm{M}$ guanidine hydrochloride $(200 \mu \mathrm{L})$, and the absorbance read at $370 \mathrm{~nm}$ against a guanidine hydrochloride blank. Protein carbonyl content was computed with a molar coefficient of $22,000 \mathrm{M}^{-1} \mathrm{~cm}^{-1}$ and expressed in $\mathrm{nM}$ carbonyl $\mathrm{mg}^{-1}$ protein. 


\subsubsection{Enzymatic Antioxidant Activity}

Extraction of enzymes was performed following Farrant et al. [85]. Three replicates of $0.25 \mathrm{~g}$ seeds each were ground with liquid nitrogen (LN) and suspended in $4 \mathrm{~mL}$ of $0.1 \mathrm{M}$ sodium phosphate buffer (pH7.8), containing $0.1 \mathrm{mM}$ EDTA, $2 \mathrm{mM}$ dithiothreitol, $1.25 \mathrm{mM}$ PEG 4000 and $0.1 \mathrm{~g}$ PVP. This was then centrifuged (Model J-E, Beckman Coulter Avanti ${ }^{\circledR}$, La Brea, CA, USA) at $4{ }^{\circ} \mathrm{C}$ for $30 \mathrm{~min}$ at $16,000 \times g$. The supernatant was separated and used to estimate CAT, GR and SOD as described below.

Catalase Activity

Catalase activity was estimated according to Claiborne [86]. The assay mixture containing $37.5 \mathrm{mM}$ of potassium phosphate buffer ( $\mathrm{pH} 7.0), 10 \mathrm{mM}$ of $\mathrm{H}_{2} \mathrm{O}_{2}$ and $100 \mu \mathrm{L}$ of enzyme extract was prepared in the dark. A UV-Vis spectrophotometer (Shimadzu UV-2600, Kyoto, Japan) was used to measure the breakdown of $\mathrm{H}_{2} \mathrm{O}_{2}$ as a decline in absorbance at $240 \mathrm{~nm}$. The activity was computed with an extinction coefficient of $0.0436 \mathrm{mM}^{-1} \mathrm{~cm}^{-1}$ and expressed in $\mu \mathrm{mol} \mathrm{H}_{2} \mathrm{O}_{2}$ decomposed $\mathrm{min}^{-1} \mathrm{~g}^{-1} \mathrm{FM}$.

\section{Glutathione Reductase}

Glutathione reductase activity was assayed using the method of Esterbauer and Grill [87] as modified by Farrant et al. [85]. The assay mixture contained $50 \mathrm{mM}$ potassium phosphate buffer (pH 7.8), $3 \mathrm{mM} \mathrm{MgCl} 2,10 \mathrm{mM} \mathrm{GSSG}, 0.5 \mathrm{mM} \mathrm{NADPH}$ and $50 \mu \mathrm{L}$ of enzyme extract. The absorbance was measured at $340 \mathrm{~nm}$ against potassium phosphate buffer blank. The activity was computed using an extinction coefficient of $6.22 \mathrm{mM}^{-1} \mathrm{~cm}^{-1}$ and expressed in $\mu \mathrm{mol}$ NADPH oxidised $\mathrm{min}^{-1} \mathrm{~g}^{-1} \mathrm{FM}$.

\section{Superoxide Dismutase}

The estimation of superoxide dismutase (SOD) was based on Beauchamp and Fridovich [88] as modified by Varghese et al. [89]. The assay mixture comprised $50 \mathrm{mM}$ sodium phosphate buffer, $1.17 \mu \mathrm{M}$ riboflavin, $0.01 \mathrm{M}$ methionine, $0.056 \mathrm{mM}$ nitroblue tetrazolium (NBT) and $100 \mu \mathrm{L}$ extract. The assay mixture was pipetted into a cuvette, which was placed on an aluminium foil plate and illuminated with 55-W white fluorescent light (Philips, Johannesburg, South Africa). Enzyme activity was estimated with the enzymatic inhibition of NBT photoreduction. A unit SOD corresponded to $50 \%$ inhibition of NBT photoreduction by the enzyme. The activity was expressed in units of SOD g ${ }^{-1} \mathrm{FM}$.

\subsubsection{Germination Associated Enzymes}

$\alpha$-Amylase Activity

Enzymes were extracted according to Biswas et al. [90] with slight modifications by Farashah et al. [91]. Three replicates of $0.25 \mathrm{~g}$ seeds were ground with $\mathrm{LN}$ and suspended in $2.5 \mathrm{~mL}$ of chilled 0.1 M phosphate buffer ( $\mathrm{pH}$ 7.2). The homogenate was centrifuged (Model J-E, Beckman Coulter Avanti ${ }^{\circledR}$, La Brea, CA, USA) for 25 min at $10,000 \mathrm{rpm}$ and $4{ }^{\circ} \mathrm{C}$ and the supernatant decanted. After that, $\alpha$-amylase activity was measured according to Bernfeld [92] and Baker [93] with slight modifications by Farashah et al. [91]. Starch solution $(1 \% w / v)$, prepared in phosphate buffer, was added to $50 \mu \mathrm{L}$ extract. The reaction mixture was kept at $37^{\circ} \mathrm{C}$ for $30 \mathrm{~min}$ and mixed with $100 \mu \mathrm{L}$ dinitrosalicylic acid reagent. The mixture was boiled for $10 \mathrm{~min}$, and DW $(350 \mu \mathrm{L})$ was added to it. The absorbance of this mixture was measured at $540 \mathrm{~nm}$. The activity was defined as the amount of enzyme that liberated $1 \mu \mathrm{mol}$ of reducing sugar (maltose) $\mathrm{min}^{-1} \mathrm{ml}^{-1} \mathrm{~g}^{-1} \mathrm{FM}$.

\section{$\beta$-1,3-Glucanase Activity}

The enzyme was extracted using the method described by Farashah et al. [91]. Three replicates of $0.25 \mathrm{~g}$ seeds were ground with $\mathrm{LN}$ and suspended in $2.5 \mathrm{~mL}$ of $15 \mathrm{mM}$ sodium acetate buffer (pH 5.5). This was centrifuged (Model J-E, Beckman Coulter Avanti ${ }^{\circledR}$, La Brea, CA, USA) for 5 min at 10,000 rpm and $4{ }^{\circ} \mathrm{C}$. The $\beta$-1,3-glucanase activity was estimated as described by Celestino et al. [94] with slight 
modifications. The assay mixture comprised of laminarin $(1 \% w / v)$ dissolved in $100 \mathrm{mM}$ sodium acetate buffer (pH 5.0) and $50 \mu \mathrm{L}$ of extract. This was kept for $30 \mathrm{~min}$ at $50{ }^{\circ} \mathrm{C}$ before DNS reagent $(300 \mu \mathrm{L})$ was added to it. The mixture was then boiled for $5 \mathrm{~min}$, and the absorbance measured at $550 \mathrm{~nm}$. The activity was defined as the amount of enzyme that liberated $1 \mu \mathrm{mol}$ of reducing sugar (glucose) $\min ^{-1} \mathrm{ml}^{-1} \mathrm{~g}^{-1} \mathrm{FM}$.

\subsection{Statistical Analysis}

Data were analysed with IBM SPSS Statistics (Ver. 26.0. Armonk, NY, USA). Normality was tested for using a Shapiro-Wilk test. Percentage data were arcsine transformed before analysis. To test for significance, normal seedling (\%) data, vigour index and biochemical parameters were subjected to ANOVA where data were parametric. Separation of means was done using a Tukey post-hoc test. Where data did not satisfy the assumptions of ANOVA, even after transformation, a Kruskal-Wallis test was used. Differences were regarded as significant at 0.05 level of probability.

\section{Conclusions}

Overall, the exogenous application of inorganic salt solutions as pre-hydration treatments for orthodox seeds invigoration was beneficial in improving normal seedling production of lettuce and seedling vigour of both cabbage and lettuce seeds subjected to $\mathrm{CD}$. In this regard, $\mathrm{CaCl}_{2} \mathrm{CW}, \mathrm{CaMg}$, $\mathrm{CaMg} \mathrm{CW}$ (6.5), $\mathrm{MgCl}_{2} \mathrm{CW}, \mathrm{NaCl} \mathrm{CW}$ and $\mathrm{NaCl} \mathrm{CW} \mathrm{(6.5)} \mathrm{are} \mathrm{the} \mathrm{best} \mathrm{pre-hydration} \mathrm{treatments} \mathrm{having}$ promotive effects on CDd lettuce seeds in terms of normal seedling production. In terms of seedling vigour, $\mathrm{CaMg}$, $\mathrm{CaMg} \mathrm{CW}$ (6.5), $\mathrm{NaCl} \mathrm{CW}$ and $\mathrm{NaCl} \mathrm{CW} \mathrm{(6.5)} \mathrm{have} \mathrm{promotive} \mathrm{effect} \mathrm{in} \mathrm{CDd} \mathrm{cabbage}$ seeds, and $\mathrm{CaCl}_{2}, \mathrm{CaCl}_{2} \mathrm{CW}, \mathrm{CaMg}$, $\mathrm{CaMg} \mathrm{CW}$ (6.5), $\mathrm{MgCl}_{2} \mathrm{CW}, \mathrm{NaCl} \mathrm{CW}$ and $\mathrm{NaCl} \mathrm{CW}$ (6.5) in CDd lettuce seeds.

The promotive effects of the inorganic salt pre-treatment solutions appear to be based on the stimulation of antioxidative and germination-related enzymes activities in lettuce, which in turn enhances energy metabolisms, early mobilisation of stored food and endosperm weakening. At the same time, the promotive effect on cabbage seedling vigour might be purely a functional nutrient $[95,96]$ effect for growth-related events.

The findings of the present study also suggest that the essentiality of calcium ions $\left(\mathrm{Ca}^{2+}\right)$ in conjunction with the plausible restorative strength of CW contribute to the substantial increase in normal seedling production in lettuce, irrespective of the $\mathrm{pH}$ of the treatment solutions or extent of deterioration (for P50 and P25 at least).

Importantly, the results suggest that the inorganic salt hydration treatment effects are based on the direct reductive power of CW and the stimulation of endogenous antioxidants (GR and SOD), which in turn mitigate the effects of stress-induced oxidative injury (e.g., reduced EC, lipid peroxidation and protein carbonylation) in lettuce seeds. Additionally, pre-hydration treatment with specific inorganic ion solutions (and even DW) enhance germination enzyme activities in lettuce seeds.

In terms of recommendations, seed bank practitioners should note that the effects of the inorganic salt hydration treatments appear to be dependent on the nature of the main oxidants and oxidant targets in specific species. For example, the oxidant(s) and oxidant target(s) in cabbage appear to be different from that in lettuce, and by implication, the promotive effect of specific hydration treatments differed between species.

The results also suggest that certain hydration treatments may improve cellular function in deteriorated seeds by influencing intracellular $\mathrm{Ca}^{2+}$ and $\mathrm{K}^{+}$levels, and this should form part of future studies.

Supplementary Materials: The following are available online at http://www.mdpi.com/2223-7747/9/9/1164/s1, Figure S1: Water uptake in cabbage and lettuce seeds, Figure S2: Normal seedling production (\%) after controlled deterioration of cabbage (A) and lettuce (B) seeds 14 days after germination, Table S1: Effect of the application of inorganic salt solutions on seedling vigour index of fresh and controlled deteriorated (P75) cabbage and lettuce seeds, Table S2: Effect of the application of inorganic salt solutions on mortality (\%) in fresh and controlled deteriorated cabbage and lettuce seeds. 
Author Contributions: A.E.A. did the experimental work, analysed the data and wrote the original manuscript as supervised by S., B.V. and N.W.P. All authors have read and agreed to the published version of the manuscript.

Funding: This work was funded by research grant by the National Research Foundation of South Africa to N.W. Pammenter (grant number CPRR13092145823). The APC was partially funded by the University of KwaZulu-Natal, South Africa.

Conflicts of Interest: The authors declare no conflict of interest.

\section{References}

1. Tekrony, D.M.; Egli, D.B. Accumulation of seed vigour during development and maturation. Basic and applied aspects of seed biology. In Current Plant Science and Biotechnology in Agriculture; Ellis, R.H., Black, M., Murdoch, A.J., Hong, T.D., Eds.; Springer: Dordrecht, The Netherlands, 1997; Volume 30, pp. 369-384.

2. Dayal, A.; Rangare, N.; Kumar, A.; Kumari, M. Effect of physiological maturity on seed quality of maize (Zea mays L.). Forage Res. 2014, 40, 1-6.

3. Ibrahim, A.E.; Roberts, E.H. Viability of lettuce seeds: I. Survival in hermetic storage. J. Exp. Bot. 1983, 34, 620-630. [CrossRef]

4. Walters, C.; Towill, L. Seeds and pollen. In Agriculture Handbook. The Commercial Storage of Fruits, Vegetables, and Florist and Nursery Stocks; Gross, K.C., Wang, C.Y., Saltveit, M., Eds.; USDA-ARS, National Center for Genetic Resources Preservation Preservation of Plant Germplasm Research: Fort Collins, CO, USA, 2004; pp. 735-743, ISBN 3015046128.

5. Basra, S.M.A.; Ahmad, N.; Khan, M.M.; Iqbal, N.; Cheema, M.A. Assessment of cottonseed deterioration during accelerated ageing. Seed Sci. Technol. 2003, 31, 531-540. [CrossRef]

6. Poonguzhali, S. Improving vigour and viability of blackgram cv.co 6 [Vigna mungo (L) Hepper] through seed priming with inorganics. Legum. Res.-Int. J. 2016, 39, 820-829. [CrossRef]

7. Trawatha, S.E.; TeKrony, D.M.; Hildebrand, D.F. Relationship of soybean seed quality to fatty acid and c6-aldehyde levels during storage. Crop Sci. 1995, 35, 1415-1422. [CrossRef]

8. Shaban, M. Review on Physiological aspects of seed deterioration. Int. J. Agric. Crop Sci. 2013, 6, 627-631.

9. Kibinza, S.; Vinel, D.; Côme, D.; Bailly, C.; Corbineau, F. Sunflower seed deterioration as related to moisture content during ageing, energy metabolism and active oxygen species scavenging. Physiol. Plant. 2006, 128, 496-506. [CrossRef]

10. Nagel, M.; Kranner, I.; Neumann, K.; Rolletschek, H.; Seal, C.E.; Colville, L.; Fernández-Marín, B.; Börner, A. Genome-wide association mapping and biochemical markers reveal that seed ageing and longevity are intricately affected by genetic background and developmental and environmental conditions in barley. Plant Cell Environ. 2015, 38, 1011-1022. [CrossRef]

11. Jatoi, S.A.; Afzal, M.; Nasim, S.; Anwar, R. Seed deterioration study in pea, using accelerated ageing techniques. Pak. J. Biol. Sci. 2001, 4, 1490-1494.

12. Saxena, O.P.; Singh, G.; Pakeeraiah, T.; Pandey, N. Seed deterioration studies in some vegetable seeds. Acta Hortic. 1987, 39-44. [CrossRef]

13. Lee, H.-S.; Jeon, Y.-A.; Lee, Y.-Y.; Lee, S.-Y.; Kim, Y.-G. Comparison of Seed Viability Among 42 Species Stored in a Genebank. Korean J. Crop Sci. 2013, 58, 432-438. [CrossRef]

14. Hill, H.; Bradford, K.J.; Cunningham, J.; Taylor, A.G. Primed Lettuce Seeds Exhibit Increased Sensitivity to Moisture Content During Controlled Deterioration. HortScience 2007, 42, 1436-1439. [CrossRef]

15. Leprince, O.; Harren, F.J.M.; Buitink, J.; Alberda, M.; Hoekstra, F.A. Metabolic dysfunction and unabated respiration precede the loss of membrane integrity during dehydration of germinating radicles. Plant Physiol. 2000, 122, 597-608. [CrossRef]

16. Saed-Moucheshi, A.; Shekoofa, A.; Pessarakli, M. Reactive oxygen species (ROS) generation and detoxifying in plants. J. Plant Nutr. 2014, 37, 1573-1585. [CrossRef]

17. Mittler, R. ROS are good. Trends Plant Sci. 2017, 22, 11-19. [CrossRef] [PubMed]

18. Mira, S.; Estrelles, E.; González-Benito, M.E.; Corbineau, F. Biochemical changes induced in seeds of Brassicaceae wild species during ageing. Acta Physiol. Plant. 2011, 33, 1803-1809. [CrossRef]

19. Feng, J.; Shen, Y.; Shi, F.; Li, C. Changes in seed germination ability, lipid peroxidation and antioxidant enzyme activities of Ginkgo biloba seed during desiccation. Forests 2017, 8, 286. [CrossRef] 
20. Sahu, B.; Sahu, A.K.; Thomas, V.; Naithani, S.C. Reactive oxygen species, lipid peroxidation, protein oxidation and antioxidative enzymes in dehydrating Karanj (Pongamia pinnata) seeds during storage. South African J. Bot. 2017, 112, 383-390. [CrossRef]

21. Al-maskri, A.; Kharr, M.M.; Ai-mantheriand, O.; Al-habs, K. Effect of accelerated aging on lipid peroxidation, leakage and seedling vigor (RGR) in cucumber (Cucumis sativus L.) seeds. Park. J Agri. Sci 2002, 39, 330-337.

22. Parkhey, S.; Naithani, S.C.; Keshavkant, S. ROS production and lipid catabolism in desiccating Shorea robusta seeds during aging. Plant Physiol. Biochem. 2012, 57, 261-267. [CrossRef]

23. Kalemba, E.M.; Pukacka, S. Carbonylated proteins accumulated as vitality decreases during long-term storage of beech (Fagus sylvatica L.) seeds. Trees 2014, 28, 503-515. [CrossRef]

24. Mirdad, Z.; Powell, A.A.; Matthews, S. Prediction of germination in artificially aged seeds of Brassica spp. using the bulk conductivity test. Seed Sci. Technol. 2006, 34, 273-286. [CrossRef]

25. Smith, M.T. Membrane Changes and Lipid Peroxidation during Ageing in Seeds of Lactuca sativa L.; University of Natal: Durban, South Africa, 1986.

26. Mira, S.; González-Benito, M.E.; Hill, L.M.; Walters, C. Characterization of volatile production during storage of lettuce (Lactuca sativa) seed. J. Exp. Bot. 2010, 61, 3915-3924. [CrossRef] [PubMed]

27. Bradford, K.J.; Steiner, J.J.; Trawatha, S.E. Seed priming influence on germination and emergence of pepper seed lots. Crop Sci. 1990, 30, 718-721. [CrossRef]

28. Jett, L.W.; Welbaum, G.E.; Morse, R.D. Effects of matric and osmotic priming treatments on broccoli seed germination. J. Am. Soc. Hortic. Sci. 1996, 121, 423-429. [CrossRef]

29. Delian, E.; Bădulescu, L.; Dobrescu, A.; Chira, L.; Lagunovschi-Luchian, V. A brief overview of seed priming benefits in tomato. Rom. Biotechnol. Lett. 2017, 22, 12505-12513.

30. Mondal, S.; Bose, B. An impact of seed priming on disease resistance: A review. In Microbial Diversity and Biotechnology in Food Security; Kharwar, R.N., Upadhyay, R.S., Dubey, N.K., Raghuwanshi, R., Eds.; Springer India: New Delhi, India, 2014; pp. 193-203, ISBN 978-81-322-1800-5.

31. Abdolahi, M.; Andelibi, B.; Zangani, E.; Shekari, F.; Jamaati-E-Somarin, S. Effect of accelerated aging and priming on seed germination of rapeseed (Brassica napus L.) cultivars. Int. Res. J. Appl. Basic Sci. 2012, 3, 499-508.

32. Jisha, K.C.; Vijayakumari, K.; Puthur, J.T. Seed priming for abiotic stress tolerance: An overview. Acta Physiol. Plant. 2013, 35, 1381-1396. [CrossRef]

33. Varier, A.; Vari, A.K.; Dadlani, M. The subcellular basis of seed priming. Curr. Sci. 2010, 99, 450-456.

34. Carrozzi, L.E.; Creus, C.M.; Barassi, C.A.; Monterubbianesi, G.; Di Benedetto, A. Reparation of aged lettuce (Lactuca sativa) seeds by osmotic priming and Azospirillum brasilense inoculation. Botany 2012, 90, 1093-1102. [CrossRef]

35. Khan, H.A.; Ayub, C.; Pervez, M.A.; Bilal, R.M.; Shahid, M.; Zaif, K. Effect of seed priming with $\mathrm{NaCl}$ on salinity tolerance of hot pepper (Capsicum annuum L.) at seedling stage. Soil Environ. 2009, 28, 81-87.

36. Batool, A.; Ziaf, K.; Amjad, M. Effect of halo-priming on germination and vigor index of cabbage (Brassica oleracea var. capitata). J. Environ. Agric. Sci. 2015, 2.

37. Ashraf, M.; Rauf, H. Inducing salt tolerance in maize (Zea mays L.) through seed priming with chloride salts: Growth and ion transport at early growth stages. Acta Physiol. Plant. 2001, 23, 407-414. [CrossRef]

38. Pasqua, G.; Manes, F.; Monacelli, B.; Natale, L.; Anselmi, S. Effects of the culture medium pH and ion uptake in in vitro vegetative organogenesis in thin cell layers of tobacco. Plant Sci. 2002, 162, 947-955. [CrossRef]

39. Berjak, P.; Sershen; Varghese, B.; Pammenter, N.W. Cathodic amelioration of the adverse effects of oxidative stress accompanying procedures necessary for cryopreservation of embryonic axes of recalcitrant-seeded species. Seed Sci. Res. 2011, 21, 187-203. [CrossRef]

40. Hanaoka, K. Antioxidant effects of reduced water produced by electrolysis of sodium chloride solutions. J. Appl. Electrochem. 2001, 31, 1307-1313. [CrossRef]

41. Gondwe, D.S.B.; Berjak, P.; Pammenter, N.W.; Sershen; Varghese, B. Effect of priming with cathodic water and subsequent storage on invigoration of Pisum sativum, Cucurbita maxima and Lycopersicon esculentum seeds. Seed Sci. Technol. 2016, 44, 370-381. [CrossRef]

42. Hanaoka, K.; Sun, D.; Lawrence, R.; Kamitani, Y.; Fernandes, G. The mechanism of the enhanced antioxidant effects against superoxide anion radicals of reduced water produced by electrolysis. Biophys. Chem. 2004, 107, 71-82. [CrossRef] 
43. Nawaz, J.; Hussain, M.; Jabbar, A.; Nadeem, G.A.; Sajid, M.; Subtain, M.; Shabbir, I. Seed priming a technique. Int. J. Agric. Crop Sci. 2013, 6, 1373-1381.

44. Naidoo, C.; Berjak, P.; Pammenter, N.W.; Varghese, B. The role of reactive oxygen species and antioxidants during precooling stages of axis cryopreservation in recalcitrant Trichilia dregeana. Botany 2016, 94, 391-403. [CrossRef]

45. Sivritepe, N.; Sivritepe, H.Ö. Organic priming with seaweed extract (Ascophyllum nodosum) affects viability of pepper seeds. Asian J. Chem. 2008, 20, 5689-5694.

46. Tarquis, A.M.; Bradford, K.J. Prehydration and priming treatments that advance germination also increase the rate of deterioration of lettuce seeds. J. Exp. Bot. 1992, 43, 307-317. [CrossRef]

47. Hawkins, C.L.; Morgan, P.E.; Davies, M.J. Quantification of protein modification by oxidants. Free Radic. Biol. Med. 2009, 46, 965-988. [CrossRef] [PubMed]

48. Kaczmarek, M.; Fedorowicz-Strońska, O.; Głowacka, K.; Waśkiewicz, A.; Sadowski, J. CaCl ${ }_{2}$ treatment improves drought stress tolerance in barley (Hordeum vulgare L.). Acta Physiol. Plant. 2017, 39, 41. [CrossRef]

49. Larkindale, J.; Knight, M.R. Protection against heat stress-induced oxidative damage in arabidopsis involves calcium, abscisic acid, ethylene, and salicylic acid. Plant Physiol. 2002, 128, 682-695. [CrossRef]

50. Demidchik, V. Reactive oxygen species, oxidative stress and plant ion channels. In Ion Channels and Plant Stress Responses. Signaling and Communication in Plants; Demidchik, V., Maathuis, F., Eds.; Signaling and Communication in Plants; Springer Berlin Heidelberg: Berlin/Heidelberg, Germany, 2010; pp. 207-232.

51. Bailly, C. Active oxygen species and antioxidants in seed biology. Seed Sci. Res. 2004, 14, 93-107. [CrossRef]

52. Gill, S.S.; Tuteja, N. Reactive oxygen species and antioxidant machinery in abiotic stress tolerance in crop plants. Plant Physiol. Biochem. 2010, 48, 909-930. [CrossRef]

53. Foreman, J.; Demidchik, V.; Bothwell, J.H.F.; Mylona, P.; Miedema, H.; Torres, M.A.; Linstead, P.; Costa, S.; Brownlee, C.; Jones, J.D.G.; et al. Reactive oxygen species produced by NADPH oxidase regulate plant cell growth. Nature 2003, 422, 442-446. [CrossRef]

54. Demidchik, V.; Shabala, S.N.; Coutts, K.B.; Tester, M.A.; Davies, J.M. Free oxygen radicals regulate plasma membrane $\mathrm{Ca}_{2}{ }^{+}$- and $\mathrm{K}^{+}$-permeable channels in plant root cells. J. Cell Sci. 2003, 116, 81-88. [CrossRef]

55. Sanders, D.; Brownlee, C.; Harper, J.F. Communicating with calcium. Plant Cell 1999, 11, 691-706. [CrossRef]

56. Demidchik, V.; Straltsova, D.; Medvedev, S.S.; Pozhvanov, G.A.; Sokolik, A.; Yurin, V. Stress-induced electrolyte leakage: The role of $\mathrm{K}^{+}$-permeable channels and involvement in programmed cell death and metabolic adjustment. J. Exp. Bot. 2014, 65, 1259-1270. [CrossRef] [PubMed]

57. Iqbal, M.; Ashraf, M. Seed preconditioning modulates growth, ionic relations, and photosynthetic capacity in adult plants of hexaploid wheat under salt stress. J. Plant Nutr. 2007, 30, 381-396. [CrossRef]

58. Ree, J.F.; Guerra, M.P. Exogenous inorganic ions, partial dehydration, and high rewarming temperatures improve peach palm (Bactris gasipaes Kunth) embryogenic cluster post-vitrification regrowth. Plant Cell Tissue Organ Cult. 2020. [CrossRef]

59. Sathish, S.; Sundareswaran, S. Biochemical evaluation of seed priming in fresh and aged seeds of maize hybrid [COH(M) 5] and its parental lines. Curr. Biot. 2010, 4, 162-170.

60. Chowdhury, S.R.; Choudhuri, M.A. Effects of $\mathrm{CaCl}_{2}$ and $\mathrm{ABA}$ on changes in $\mathrm{H}_{2} \mathrm{O}_{2}$, metabolism in two jute species under water deficit stress. J. Plant Physiol. 1989, 135, 179-183. [CrossRef]

61. Khorshidi, M.; Nojavan, A.M. The effects of abscisic acid and $\mathrm{CaCl}_{2}$ on the activities of antioxidant enzymes under cold stress in maize seedlings in the dark. Pakistan J. Biol. Sci. 2006, 9, 54-59. [CrossRef]

62. Wang, H.Y.; Chen, C.L.; Sung, J.M. Both warm water soaking and matriconditioning treatments enhance anti-oxidation of bitter gourd seeds germinated at sub-optimal temperature. Seed Sci. Technol. 2003, 31, 47-56. [CrossRef]

63. Farooq, M.; Basra, S.M.A.; Wahid, A.; Khaliq, A.; Kobayashi, N. Rice seed invigoration: A review. In Organic Farming, Pest Control and Remediation of Soil Pollutants; Sustainable Agriculture Reviews; Lichtfouse, E., Ed.; Springer Netherlands: Dordrecht, The Netherlands, 2009; Volume 1, pp. 137-175, ISBN 978-1-4020-9653-2.

64. de Oliveira, A.B.; Gomes-Filho, E.; Enéas-Filho, J.; Prisco, J.T.; Alencar, N.L.M. Seed priming effects on growth, lipid peroxidation, and activity of ROS scavenging enzymes in $\mathrm{NaCl}$-stressed sorghum seedlings from aged seeds. J. Plant Interact. 2012, 7, 151-159. [CrossRef]

65. Mano, J.; Biswas, M.S.; Sugimoto, K. Reactive carbonyl species: A missing link in ROS signaling. Plants 2019, 8, 391. [CrossRef] 
66. Juszczuk, I.M.; Tybura, A.; Rychter, A.M. Protein oxidation in the leaves and roots of cucumber plants (Cucumis sativus L.), mutant MSC16 and wild type. J. Plant Physiol. 2008, 165, 355-365. [CrossRef]

67. Bailly, C.; El-Maarouf-Bouteau, H.; Corbineau, F. From intracellular signaling networks to cell death: The dual role of reactive oxygen species in seed physiology. Comptes Rendus-Biol. 2008, 331, 806-814. [CrossRef] [PubMed]

68. Dell'Aquila, A. Wheat seed ageing and embryo protein degradation. Seed Sci. Res. 1994, 4, $293-298$. [CrossRef]

69. Pyngrope, S.; Bhoomika, K.; Dubey, R.S. Oxidative stress, protein carbonylation, proteolysis and antioxidative defense system as a model for depicting water deficit tolerance in Indica rice seedlings. Plant Growth Regul. 2013, 69, 149-165. [CrossRef]

70. Larson, R.A. Plant defenses against oxidative stress. Arch. Insect Biochem. Physiol. 1995, 29, $175-186$. [CrossRef] [PubMed]

71. Siadat, S.A.; Moosavi, A.; Zadeh, M.S. Effects of seed priming on antioxidant activity and germination characteristics of maize seeds under different ageing treatment. Res. J. Seed Sci. 2012, 5, 51-62. [CrossRef]

72. Demirkaya, M.; Dietz, K.J.; Sivritepe, H.O. Changes in antioxidant enzymes during ageing of onion seeds. Not. Bot. Horti Agrobot. Cluj-Napoca 2010, 38, 49-52. [CrossRef]

73. Joshi, R. Role of Enzymes in seed germination. Int. J. Creat. Res. Thoughts 2018, 6, 1-5. [CrossRef]

74. Simmons, C.R. The Physiology and Molecular Biology of Plant 1,3- $\beta$-D-Glucanases and 1,3;1,4- $\beta$-D-Glucanases; Taylor \& Francis Group: Abingdon, UK, 1994; Volume 13, ISBN 0735268940.

75. Kotake, T.; Nakagawa, N.; Takeda, K.; Sakurai, N. Auxin-induced elongation growth and expressions of cell wall-bound exo- and endo- $\beta$-glucanases in barley coleoptiles. Plant Cell Physiol. 2000, 41, 1272-1278. [CrossRef]

76. Weir, B.L.; Paulson, K.N.; Lorenz, O. A The effect of ammoniacal nitrogen on lettuce (Lactuca saliva) and radish (Raphanus sativus) Plants. Soil Sci. Soc. Am. 1972, 462-465. [CrossRef]

77. Komba, C.G.; Brunton, B.J.; Hampton, J.G. Accelerated ageing vigour testing of kale (Brassica oleracea L. var. acephala DC) seed. Seed Sci. Technol. 2006, 34, 205-208. [CrossRef]

78. Tekrony, D.M. Accelerated aging test: Principles and procedures. Seed Technol. 2005, 27, 135-146.

79. Mycock, D.J. Addition of calcium and magnesium to a glycerol and sucrose cryoprotectant solution improves the quality of plant embryo recovery from cryostorage. Cryo-Letters 1999, 20, 77-82.

80. Gebashe, F.C. Studies on the Cryopreservation of Shoot Apices from Recalcitrant-Seeded Trichilia emetica Vahl. and Trichilia dregeana Sond. Master's Thesis, Durban University of Technology, Durban, South Africa, 2015.

81. Brocklehurst, P.A.; Dearman, J.; Drew, R.L.K. Effects of osmotic priming on seed germination and seedling growth in leek. Sci. Hortic. (Amsterdam) 1984, 24, 201-210. [CrossRef]

82. Sershen; Varghese, B.; Naidoo, C.; Pammenter, N.W. The use of plant stress biomarkers in assessing the effects of desiccation in zygotic embryos from recalcitrant seeds: Challenges and considerations. Plant Biol. 2016, 18, 433-444. [CrossRef] [PubMed]

83. Bradford, M.M. A rapid and sensitive method for the quantitation of microgram quantities of protein utilizing the principle of protein-dye binding. Anal. Biochem. 1976, 72, 248-254. [CrossRef]

84. Augustyniak, E.; Adam, A.; Wojdyla, K.; Rogowska-wrzesinska, A.; Willetts, R.; Korkmaz, A.; Atalay, M.; Weber, D.; Grune, T.; Borsa, C.; et al. Validation of protein carbonyl measurement: A multi-centre study. Redox Biol. 2015, 4, 149-157. [CrossRef]

85. Farrant, J.M.; Bailly, C.; Leymarie, J.; Hamman, B.; Come, D.; Corbineau, F. Wheat seedlings as a model to understand desiccation tolerance and sensitivity. Physiol. Plant. 2004, 120, 563-574. [CrossRef]

86. Claiborne, A. Catalase activity. In Greenwald EA (ed) CRC Handbook of Methods for Oxygen Radical Research; CRC Press: Boca Raton, FL, USA, 1985; pp. 283-284.

87. Esterbauer, H.; Grill, D. Seasonal variation of glutathione and glutathione reductase in needles of Picea abies. Plant Physiol. 1978, 61, 119-121. [CrossRef]

88. Beauchamp, C.; Fridovich, I. Superoxide dismutase: Improved assays and an assay applicable to acrylamide gels. Anal. Biochem. 1971, 44, 276-287. [CrossRef]

89. Varghese, B.; Sershen; Berjak, P.; Varghese, D.; Pammenter, N.W. Differential drying rates of recalcitrant Trichilia dregeana embryonic axes: A study of survival and oxidative stress metabolism. Physiol. Plant. 2011, 142, 326-338. [CrossRef] 
90. Biswas, P.K.; Devi, A.; Roy, P.K.; Paul, K.B. Enzyme activity in dormant and nondormant large crabgrass (Digitaria sanguinalis) seeds following hydration. Weed Sci. 1978, 26, 90-93. [CrossRef]

91. Farashah, D.H.; Afshari, T.R.; Sharifzadeh, F.; Chavoshinasab, S. Germination improvement and $\alpha$-amylase and $\beta$-1,3-glucanase activity in dormant and nondormant seeds of oregano (Origanum vulgare). Aust. J. Crop Sci. 2011, 5, 421-427.

92. Bernfeld, P. Amylases, alpha and $\beta$. Methods Enzymol. I 1955, I, 149-158. [CrossRef]

93. Baker, J.E. Purification and partial characterization of $\alpha$-amylase allozymes from the lesser grain borer, Rhyzopertha dominica. Insect Biochem. 1991, 21, 303-311. [CrossRef]

94. Celestino, K.R.S.; Cunha, R.B.; Felix, C.R. Characterization of a $\beta$-glucanase produced by Rhizopus microsporus var. microsporus, and its potential for application in the brewing industry. BMC Biochem. 2006, 7, 23. [CrossRef]

95. Subbarao, G.V.; Ito, O.; Berry, W.L.; Wheeler, R.M. Sodium-a functional plant nutrient. CRC. Crit. Rev. Plant Sci. 2003, 22, 391-416. [CrossRef]

96. Kronzucker, H.J.; Coskun, D.; Schulze, L.M.; Wong, J.R.; Britto, D.T. Sodium as nutrient and toxicant. Plant Soil 2013, 369, 1-23. [CrossRef]

(C) 2020 by the authors. Licensee MDPI, Basel, Switzerland. This article is an open access article distributed under the terms and conditions of the Creative Commons Attribution (CC BY) license (http://creativecommons.org/licenses/by/4.0/). 